NBER WORKING PAPER SERIES

\title{
THE OTHER SIDE OF THE TRADEOFF: THE IMPACT OF RISK ON EXECUTIVE COMPENSATION
}

\author{
Rajesh Aggarwal
}

Andrew A. Samwick

Working Paper 6634

http://www.nber.org/papers/w6634

\author{
NATIONAL BUREAU OF ECONOMIC RESEARCH \\ 1050 Massachusetts Avenue \\ Cambridge, MA 02138 \\ July 1998
}

We thank Sheri Aggarwal, Bob Gibbons, Mike Knetter, David Yermack, Sang-Seung Yi, seminar participants at Brown and Dartmouth, and especially the referee for helpful comments. We thank Sarah Leonard and Evan Walsh for exceptional research assistance and Andy Halula for assistance with the ExecuComp database. Financial support from the American Compensation Association and the Presidential Scholars Program at Dartmouth College is gratefully acknowledged. The views expressed are solely ours and do not reflect the views or opinions of the American Compensation Association. Any errors are our own. Any opinions expressed are those of the author and not those of the National Bureau of Economic Research.

(C) 1998 by Rajesh Aggarwal and Andrew A. Samwick. All rights reserved. Short sections of text, not to exceed two paragraphs, may be quoted without explicit permission provided that full credit, including (C) notice, is given to the source. 
The Other Side of the Tradeoff: The Impact

of Risk on Executive Compensation

Rajesh Aggarwal and Andrew A. Samwick

NBER Working Paper No. 6634

July 1998

JEL No. G30, J33

\section{ABSTRACT}

The principal-agent model of executive compensation is of central importance to the modern theory of the firm and corporate governance, yet the existing empirical evidence supporting it is quite weak. The key predication of the model is that the executive's pay-performance sensitivity is decreasing in the variance of the firm's performance. We demonstrate strong empirical confirmation of this prediction using a comprehensive sample of executives at large corporations. In general, the pay-performance sensitivity for executives at firms with the least volatile stock prices is an order of magnitude greater than the pay-performance sensitivity for executives at firms with the most volatile stock prices. This result holds for both chief executive officers and for other highly compensated executives. We further show that estimates of the pay-performance sensitivity that do not explicitly account for the effect of the variance of firm performance are biased toward zero. We also test for relative performance evaluation of executives against the performance of other firms. We find little support for the relative performance evaluation model. Our findings suggest that executive compensation contracts incorporate the benefits of risk-sharing but do not incorporate the potential informational advantages of relative performance evaluation.

Rajesh Aggarwal Amos Tuck School Dartmouth College Hanover, NH 03755 raggarwal@tuck.dartmouth.edu
Andrew A. Samwick

Department of Economics

Dartmouth Collge

Hanover, NH 03755

and NBER

samwick@dartmouth.edu 


\section{Introduction}

Providing incentives to managers of publicly owned companies is the classic example of the principal-agent problem (Berle and Means (1932)). Managers or executives take unobserved actions that affect the returns of shareholders. The literature on principal-agent theory suggests that the primary means for the shareholders to ensure that managers take optimal actions is to tie managers' pay to the performance of their firms; that is, to provide high-powered incentives for managers to maximize the returns to shareholders. ${ }^{1}$ Managerial compensation will be correlated with the total return to shareholders, typically through ownership of the firm's stock or options on the firm's stock.

Despite the compelling logic of the principal-agent framework, there is little existing empirical support for the model when applied to executive compensation. In their recent survey of corporate governance, Shleifer and Vishny (1997, p. 774) ask, "Given the large impact of executives' actions on values of firms, why aren't very high powered incentive contracts used more often in the United States and elsewhere in the world? Is their use limited by optimal design of incentives, by fear of self-dealing, or by distributive politics?"

The evidence that managers are not given high-powered incentives is provided by the seminal article of Jensen and Murphy (1990a). They find that the compensation of chief executive officers increases by only $\$ 3.25$ per $\$ 1,000$ increase in shareholder wealth, which they interpret as being too small to provide significant incentives. They hypothesize that political forces work to reduce the pay-performance sensitivity from what would be consistent with the principal-agent model. Hall and Liebman (1997) estimate larger pay-performance sensitivities and document that the pay-performance sensitivity has grown since 1980 due to increasing ownership of stock and stock options. However, they do not conclude based on their findings that compensation contracts are efficient and, therefore, draw no inferences about the validity of the principal-agent model.

These studies are unable to support the principal-agent model because the average level of the pay-performance sensitivity cannot be used to judge the validity of the principal-agent model. Haubrich (1994) shows through numerical simulations that some parameterizations of the principal-agent model allow for pay-performance sensitivities as low as the 0.003 found by

\footnotetext{
${ }^{1}$ There are other mechanisms that may induce managers to act in the best interests of the shareholders, such as reputational concerns, competitive labor markets, and the threat of takeover, dismissal, or bankruptcy.
} 
Jensen and Murphy (1990a). A more direct test of the model focuses on its comparative static predictions. ${ }^{2}$ The standard principal-agent model posits an economic tradeoff between inducing the correct amount of unobservable effort by the agent and minimizing the amount of risk she is required to bear. In most principal-agent models, the pay-performance sensitivity will be decreasing in the riskiness or variance of the firm's performance. Executives in firms with more volatile stock prices will have less performance-based compensation.

We use the variation in stock return volatility across firms to test whether executives at riskier firms have lower pay-performance sensitivities. We find that the pay-performance sensitivity of a manager's compensation is decreasing in the variance of her firm's returns. In general, the pay-performance sensitivity for executives at firms with the least volatile stock prices is an order of magnitude greater than the pay-performance sensitivity for executives at firms with the most volatile stock prices. These findings strongly support the principal-agent model.

We also find that estimates of the pay-performance sensitivity that do not explicitly account for the variance of firm performance are biased toward zero. The variance of firm performance is an extremely important determinant of compensation, as implied by the principalagent model. Consider two firms, one with a high variance of returns and the other with a low variance of returns. Suppose that the CEOs of both firms receive the same compensation because the high variance firm had good performance and the low variance firm had poor performance. Running a regression of pay on performance, or simulating pay-performance sensitivities, without controlling for the variance of firm performance will incorrectly find no pay-performance sensitivity, since the CEO with better performance does not receive higher compensation. We find that omitting the variance of firm performance dramatically understates the average pay-performance sensitivity.

Another prediction of the principal-agent model is that executive compensation should be based not only on the returns to the firm's shareholders but on every variable that provides unique information about the action taken by the manager. ${ }^{3}$ A prominent example of such a variable is the returns of other firms in the same industry, leading to a compensation contract based on the relative performance of the manager compared to her industry rivals. The prediction

\footnotetext{
2 This point has previously been made by Garen (1994). We discuss his empirical findings below.

${ }^{3}$ This is the sufficient statistic result from Holmström's $(1979,1982)$ work on moral hazard.
} 
from the relative performance evaluation model is that, other things equal, an executive will receive lower compensation if executives of rival firms deliver higher returns to their shareholders.

The empirical literature on relative performance evaluation finds mixed results. Jensen and Murphy (1990a) find that relative performance is not an important source of managerial incentives. Gibbons and Murphy (1990) and Antle and Smith (1986) test more directly for relative performance pay and find that, holding constant the rate of return on a firm's common stock, a higher value-weighted industry rate of return lowers the growth of CEO pay. In contrast, Barro and Barro (1990) and Joh (1996) find that compensation increases with industry performance using data on banks and Japanese firms, respectively. Janakiraman, Lambert, and Larcker (1992) find that compensation increases with industry performance using accounting data and decreases with industry performance using stock return data. In Aggarwal and Samwick (1997), we find some evidence of relative performance evaluation in short-term compensation but find that long-term compensation increases with industry performance. In that paper, we argue that strategic interactions between managers at rival firms in an industry will limit the use of relative performance evaluation.

As in the case of the standard principal-agent model without relative performance evaluation, examining the average levels of the own-firm and industry pay-performance sensitivities provides only a weak test of the relative performance evaluation model. A stronger test would examine the comparative static predictions of the relative performance evaluation model. One such prediction is that executives in industries with low variance or in firms with high covariance between industry and firm returns should be subject to more relative performance evaluation than executives in industries with high variance or in firms with low covariance between industry and firm returns. If relative performance evaluation across firms in an industry is an important source of managerial incentives, then when precise industry signals are available or when covariance with the industry is high, industry performance will have a significant negative effect on executives' compensation.

We find little evidence to support the relative performance evaluation model. When the measure of firm performance is stock returns, we show in the Holmström-Milgrom (1987) model that a sufficient index for the degree of relative performance evaluation is a firm's stock beta (measured relative to its industry's return rather than the market return). The degree of relative 
performance evaluation should, in theory, be increasing in the firm's stock beta. This hypothesis is not supported by the data when firm performance is measured either as percent returns or dollar returns to shareholders. In addition, we find that other implications of the relative performance evaluation model have, at best, limited support. For example, the industry payperformance sensitivity is not typically estimated to be negative and significant.

We are aware of three previous studies that have performed analyses similar to ours: Garen (1994), Lambert and Larcker (1987), and Janakiraman, Lambert, and Larcker (1992). Garen (1994) empirically examines both the principal-agent model and the relative performance evaluation model. He tests the principal-agent model by examining whether CEOs' stock-related compensation is decreasing in the standard deviation of firm returns and whether CEOs' salarybased compensation is increasing in the standard deviation of firm returns. He finds weak evidence in support of this proposition. In none of his regressions is the coefficient on the standard deviation of firm returns statistically significant. He also finds little evidence of relative performance evaluation in firms with higher stock betas. He argues that pay in the form of salary should increase with a firm's beta while the use of stock and stock options should decrease with a firm's beta. He finds that both decrease in the firm's beta. As these results are ambiguous, we clarify the relationship between relative performance evaluation and a firm's stock beta in Section IV.

Lambert and Larcker (1987) test a principal-agent model of executive compensation in which there are two signals of managerial effort: accounting returns and stock market returns. Using salary and bonus as their measure of pay, they find weak evidence that the payperformance sensitivity is influenced by the variances of the return measures. In later work, Janakiraman, Lambert, and Larcker (1992) use time series tests to argue that there is no relative performance evaluation in accounting returns and weak evidence of relative performance evaluation in stock returns. In particular, they test a strong restriction on the data implied by a relative performance evaluation model--that any common component to shocks to firm and industry performance is completely removed by the compensation contract. This restriction is rejected--common components to shocks are not completely removed. We conduct a similar test of the relative performance evaluation model and find even less support in the data.

Our paper is organized as follows. In Section II, we describe the data used and the methodology we employ. We use data on executive compensation from Standard and Poor's 
ExecuComp dataset and stock return data from CRSP. Our sample consists of comprehensive data from the largest 1500 publicly traded companies in the United States from 1993 to 1996 and represents the largest cross-section of executives ever used to examine compensation. The data include the top five executives at each firm for each year. Unlike the previous literature, our results have implications for more than just CEOs.

In Section III, we present the results testing the principal-agent model. We find strong empirical support for the model. This is true for both CEOs and other highly compensated executives. We estimate the model for firm performance specified as dollar returns and percentage returns. We also estimate the model for compensation specified as the annual change in value of firm-specific wealth (i.e., including gains on existing holdings of stock and stock options), total annual compensation from the firm, and the change in annual compensation. For several specifications, we find that firms with the highest variance give their managers essentially no pay-performance sensitivity while those with the lowest variance give their managers substantial pay-performance sensitivity.

In Section IV, we test the relative performance evaluation model. We find little support for relative performance evaluation of CEOs or other executives. We find little support regardless of how returns are specified, of the econometric technique employed, and of the measure of compensation used. We also briefly discuss why relative performance evaluation might not be a prominent feature of executive compensation contracts. Section V concludes.

\section{Data}

In this section, we describe the data that we use to test the principal-agent and relative performance evaluation models. We use the ExecuComp dataset distributed by Standard and Poor's as a supplement to its Compustat dataset to construct our measures of executive compensation. We use stock returns from the Center for Research on Security Prices (CRSP) to calculate our measures of the variance of firm performance and its covariance with industry returns.

The ExecuComp data set contains data on total compensation for the top five executives (ranked annually by salary and bonus) at each of the firms in the S\&P 500, S\&P Midcap 400, and S\&P SmallCap 600. Due to enhanced federal reporting requirements for fiscal years ending 
after December 15, 1992, the ExecuComp data for 1993 through 1996 are virtually complete. ${ }^{4}$ The two main advantages of ExecuComp relative to other data that have been used to examine executive compensation are that it contains a very wide cross-section of firms and that it contains data not only for chief executive officers (CEOs) but for other executives as well.

Table 1a presents summary statistics for the five measures of compensation that we analyze in our empirical work. These statistics are for the 1995 sample year and are denominated in thousands of dollars. ${ }^{5}$ The first three rows of the table are our measures of "flow compensation," or the resources that the shareholders of the firm paid directly to the executive instead of keeping for themselves. Flow compensation is comprised of both short- and long-term components. Short-term compensation includes salary, bonus, and other annual payments such as gross-ups for tax liabilities, perquisites, and preferential discounts on stock purchases. Longterm compensation includes payouts from long-term incentive plans, the value of restricted stock granted, the value of stock options granted, and all other compensation such as contributions to benefit plans and severance payments.

The first row shows that flow compensation averaged \$2.3 million for CEOs and $\$ 939,000$ for other executives. The right skewness of the data is evident in the medians being about 40 percent lower at $\$ 1.4$ million and $\$ 565,000$, as well as in the maximums of $\$ 65.6$ million and \$34.7 million. The presence of outliers such as these motivates our use of median regressions below. The second row shows the dollar change in flow compensation for all executives who did not switch companies between 1994 and 1995. CEOs received an average raise of $\$ 182,000$, compared to $\$ 69,000$ for other executives. The third row reports the change in the logarithm of flow compensation, which corresponds approximately to the percent change in flow compensation. CEOs received an average raise of 6.2 percent, compared to 7.3 percent for other executives. The two measures of the change in flow compensation are less skewed than the level, showing substantial movements in both positive and negative directions.

As is well known, flow compensation is not the major source of incentives provided to top management. ExecuComp also includes data on the executives' holdings of stock in their

\footnotetext{
${ }^{4}$ See Standard and Poor's (1995) for documentation of the ExecuComp dataset. Our analysis in this paper uses the October 1997 release of the data.

${ }^{5}$ The samples used for these tabulations include only those executives at firms for which we had sufficient historical data (four years) to calculate reliable measures of stock price variance in the CRSP data set. About 200 of the firms in the sample failed to meet this criterion. Differences in the number of observations for different measures of compensation are the result of either an executive switching firms between 1994 and 1995 (in which case the change
} 
own companies and existing options on their companies' stock. The fourth row of the table adds to flow compensation the change in the market value of the executives' holdings of stock and stock options in their companies (as of the beginning of the year). This measure of compensation is denoted as the "Change in Firm-Specific Wealth." For CEOs, the change in firm-specific wealth was $\$ 24.2$ million at the mean and \$3.1 million at the median. The minimum was a loss of $\$ 114.4$ million and the maximum was a $\$ 5.6$ billion gain. For other executives, the mean of $\$ 4.2$ million and median of $\$ 1.1$ million are closer together, but the extremes of a $\$ 117.8$ million loss and a $\$ 1.1$ billion gain are similar to those for CEOs.

A drawback to ExecuComp is that the value of existing options is only reported for options that are currently "in-the-money." This implies that if a firm's stock price falls below the option's exercise price--even if this is just a small change in price--then the option is not reported on the balance sheets. A similar problem may occur for small increases in the stock price that put an option back in the money. This reporting convention will overstate a measure of the sensitivity of compensation to firm performance. An opposite problem will occur for price movements in either direction for out-of-the-money options that remain out-of-the-money. Since most options have been held for several years and were issued at the money, the net effect of these biases may not be too severe. Nonetheless, we also conduct our estimation with a measure of the change in firm-specific wealth excluding existing options. This measure is shown in the fifth row of the table. The mean and median changes in "Wealth Excluding Existing Options" for CEOs are \$21.1 million and \$2.0 million, respectively. For other executives, the mean and median are $\$ 3.1$ million and $\$ 753,000$. The extremes of the distribution are unaffected, however.

Table $1 \mathrm{~b}$ provides further evidence on the size of executives' investments in their own firms. The first row shows that 97.96 percent of CEOs and 93.61 percent of other executives own stock in their companies. The mean and median holdings, conditional on ownership, are $\$ 65.4$ million and $\$ 4.6$ million for CEOs and $\$ 8.1$ million and $\$ 648,000$ for other executives. The maximum holdings are \$16.6 billion and \$2.7 billion for CEOs and other executives, respectively. When evaluated as ownership shares of the firm, the average CEO holds 2.98 percent of her firm and the average Non-CEO holds 0.44 percent. Median holdings are about one-tenth as large, and maximum shares are 63.23 percent and 43.38 percent for CEOs and other executives, respectively. The third row reports ownership of existing options. Slightly more

in compensation does not pertain to the same firm in both years) or missing data on a component of compensation. 
than 80 percent of both CEOs and other executives have options, with conditional means of $\$ 7.3$ and \$2.2 million, respectively. Maximum values are much lower than for stock ownership, reaching only $\$ 317.9$ and $\$ 127.3$ million for the two groups. Finally, the bottom row shows that 68.9 percent of CEOs and 72.4 percent of other executives received a new option grant in 1995. The average values were $\$ 1.2$ million for CEOs and $\$ 393,000$ for other executives, representing sizable components of total flow compensation. ${ }^{6}$

Studies of executive compensation are typically based on CEOs at large publicly traded firms. As noted above, the firms in the ExecuComp sample represent the largest 1500 publicly traded corporations in the United States. In 1995, the total assets per firm were $\$ 7.9$ billion at the mean and $\$ 1.3$ billion at the median. The median firm had 5,860 employees and the mean firm had 18,450 . Sales per firm averaged $\$ 3.7$ billion, with a median of $\$ 1.1$ billion. Net income was $\$ 54.3$ million for the median firm and \$219.4 million at the mean. The Jensen and Murphy (1990b) sample consists of CEOs at the largest 430 publicly traded companies in 1988. The Hall and Liebman (1997) sample consists of CEOs at 478 companies. By comparison, our sample consists of three times as many firms and has data on five times as many executives per firm.

Our tests of the principal-agent and relative performance evaluation models exploit the cross-sectional variation in the pay-performance sensitivity. We allow the estimated payperformance sensitivity to vary with the firm's stock return volatility. We construct the variables to implement these tests from two sources.

ExecuComp provides data on the total return to shareholders in each sample year, specified in percent returns. We subtract the growth in the Consumer Price Index to examine real returns. Dollar returns to shareholders are equal to the percent returns multiplied by the market value of the firm at the beginning of the sample year, which is also reported in ExecuComp. The first two columns of Table 1c present the deciles of the distribution of both of these measures of performance over all sample years. Percent returns range from a loss of 97.38 percent to a gain of 475.71 percent, with a median return of 9.91 percent and a mean return of 14.72 percent. Dollar returns have a low of $-\$ 18.755$ billion and a high of $\$ 60.990$ billion. The median dollar return is $\$ 61$ million and the mean dollar return is $\$ 483$ million. As we discuss in Section IV, we also compute the returns to shareholders for each firm's industry using the ExecuComp data set.

\footnotetext{
${ }^{6}$ The value of stock options granted is estimated using the Black-Scholes formula, as documented in Standard and Poor's (1995).
} 
In order to compute variances and covariances of stock returns, we need data at a monthly frequency. Since Compustat reports data at quarterly or annual frequencies, we use data from CRSP to compute each company's stock return variance and covariance with industry returns. Our estimates are based on the monthly total returns to shareholders over the sixty months preceding the sample year. For example, to compute the return variance for a firm in 1993, we use the variance of monthly returns from January, 1988, to December, 1992. As in the ExecuComp data, we use real returns, including dividends and other distributions.

Our tests of the principal-agent model require only the variance of the returns to the executive's firm. The cross-sectional distribution of the standard deviation of percent returns is presented in the third column of the table. The standard deviations range from a low of 2.73 percent to a high of 32.06 percent, with mean and median standard deviations of returns of 8.82 and 8.07 percent, respectively. Our tests of the relative performance evaluation model require the variance of the idiosyncratic returns to the executive's firm and the beta of the firm's total returns with the industry returns. ${ }^{7}$ The standard deviations of the idiosyncratic returns are about a percentage point smaller than the standard deviations of the firm's returns throughout the distribution. Fewer than 10 percent of the betas measured relative to the industry are negative. The maximum beta is 3.36 . The mean and median betas are both very close to 1 , taking on values of 0.989 and 0.965 , respectively.

\section{The Principal-Agent Results}

In this section we test comparative static predictions of a standard principal-agent model. In Holmström-Milgrom (1987), firm performance is given by $\pi=x+\varepsilon$ where $\varepsilon \sim N\left[0, \sigma_{\varepsilon}{ }^{2}\right]$ and $x$ is the manager's action choice. The manager's compensation contract is given by $w=\alpha_{0}+\alpha_{1} \pi$. The optimal performance-related component of the contract, the pay-performance sensitivity, for a risk averse manager is:

$$
\alpha_{1}^{*}=\frac{1}{1+r k \sigma_{\varepsilon}^{2}}
$$

where $\sigma_{\varepsilon}^{2}$ is the variance on the measure of performance, $r$ is the manager's coefficient of

\footnotetext{
${ }^{7}$ As discussed in Section IV, the idiosyncratic return is the portion of the firm's return that is uncorrelated with the industry's return. Its variance is $\sigma_{\varepsilon}^{2}\left(1-\rho^{2}\right)$, where $\rho$ is the correlation of the firm's return with the industry return and $\sigma_{\varepsilon}{ }^{2}$ is the variance of the firm's return. The firm's beta measured relative to the industry is $\rho \sigma_{\varepsilon} / \sigma_{\theta}$, where $\sigma_{\theta}$ is the standard deviation of the industry return.
} 
absolute risk aversion, and $\mathrm{k}$ is the curvature of the agent's disutility of effort function. For our purposes, the important feature of this expression is that the manager's pay-performance sensitivity, $\alpha_{1}$, is clearly decreasing in $\sigma_{\varepsilon}^{2}$. This result is the key comparative static prediction that we test. We will specify firm performance as both dollar returns to shareholders and percentage returns to shareholders.

In this principal-agent setting, what matters for the executive's compensation is the variance of the performance measure and not the covariance of the performance measure with any other variable such as the market return. Covariance is only important in a relative performance evaluation setting, which we examine in the next section. Intuitively, covariance would matter in this setting only if the executive held a well-diversified portfolio. If the executive held a well-diversified portfolio, then the executive would maximize the value of her portfolio and not her compensation, as is assumed in the principal-agent literature. Restrictions on stock and stock option grants ensure that executives do not hold well-diversified portfolios, that they are in fact heavily invested in the stock of their own firms. Executives will therefore care about the variance of their own firms' stock, and variance is the appropriate variable to use in testing the principal-agent model.

In estimating the pay-performance sensitivity, we approximate the optimal contract for executive $i$ working at firm $j$ in year $t$ with the following linear specification:

$$
w_{i j t}=\gamma_{0}+\gamma_{1} \pi_{j t}+\gamma_{2} F\left(\sigma_{j t}^{2}\right) \pi_{j t}+\gamma_{3} F\left(\sigma_{j t}^{2}\right)+\lambda_{i}+\mu_{t}+\varepsilon_{i t} .
$$

In this specification, $\mathrm{w}_{\mathrm{ijt}}$ is the executive's compensation, $\pi_{\mathrm{jt}}$ is the return to shareholders (specified as either dollar or percentage returns), $\lambda_{\mathrm{i}}$ is an executive fixed effect, $\mu_{\mathrm{t}}$ is a year effect, and $\varepsilon_{\mathrm{it}}$ is the error term. $\mathrm{F}\left(\sigma_{\mathrm{jt}}{ }^{2}\right)$ is the cumulative distribution function of the variance of returns for firms in the sample. By using the CDF, the estimated values of $\gamma_{1}$ and $\gamma_{2}$ can be easily transformed into pay-performance sensitivities at any percentile of the distribution of variances. The pay-performance sensitivity for a manager with a given firm stock return variance is $\gamma_{1}+$ $\mathrm{F}\left(\sigma_{\mathrm{jt}}{ }^{2}\right) \gamma_{2}$. For example, a firm with the median stock return variance has a pay-performance sensitivity of $\gamma_{1}+0.5 \gamma_{2}$. CDF values of 0 and 1 correspond to the minimum and maximum observed variances in the sample, where the pay-performance sensitivities are $\gamma_{1}$ and $\gamma_{1}+\gamma_{2}$, respectively.

The principal-agent model predicts that higher returns to shareholders will lead to higher 
compensation $\left(\gamma_{1}>0\right)$ and that the effect of higher returns will be smaller at firms with more variable stock prices $\left(\gamma_{2}<0\right)$. The test of the model is based on the sensitivity of compensation to performance, not on the level of compensation itself. The principal-agent model does not give an unambiguous prediction as to whether the expected level of compensation is increasing with firm stock return variance. This implies that the model cannot be tested based on the sign of $\gamma_{3}$. However, by including the $\mathrm{CDF}$ of return variance in the regression, we ensure that our estimates of $\gamma_{2}$ are not affected by any relationship between variance and the level of compensation that may happen to exist in the cross-section. The equation also includes year effects $\left(\mu_{\mathrm{t}}\right)$ to allow for different average levels of compensation in each sample year.

To demonstrate the robustness of our empirical results, we estimate equation (2) in several different ways. To be consistent with Jensen and Murphy (1990a), we specify returns to shareholders as the dollar change in the market value of the firm over the year. This is the percentage return to shareholders (of capital gains plus dividends) multiplied by the market value of the firm at the beginning of the year. With compensation in thousands and market value in millions of constant 1995 dollars, the estimated pay-performance sensitivity of $\gamma_{1}+F\left(\sigma_{j t}{ }^{2}\right) \gamma_{2}$ is denominated in dollars of compensation for each thousand dollar increase in firm value. Note that in this regression, $\sigma_{\mathrm{jt}}{ }^{2}$ is the variance in the dollar returns to shareholders, so that we account for the fact that larger firms will tend to have larger variances by virtue of scale.

In other specifications, we specify returns as the percentage returns to shareholders. The pay-performance sensitivity is therefore thousands of dollars of compensation for each percentage point increase in returns to shareholders. Although it is commonplace in the literature to estimate dollars of compensation on percent returns to shareholders, this specification assumes that the extra compensation that the executive would receive for a one percent increase in the value of the firm is independent of the size of the firm. In a cross-section of firms, this assumption is likely to be false. We estimate this specification for consistency with the previous literature. However, we consider the specification of dollars of compensation on dollar returns to shareholders to be the appropriate one to test the principal-agent model.

Tables 1a and $1 \mathrm{~b}$ showed clearly the presence of outliers in the data on compensation. As a measure of the center of a distribution, the median is more robust to the presence of large outliers than is the mean. We therefore use median regressions to estimate pay-performance sensitivities. We will compare our estimates to those in the previous literature (Jensen and 
Murphy (1990a) and Hall and Liebman (1997)) in which pay-performance sensitivities were computed for CEOs with median stock ownership.

We also estimate pay-performance sensitivities using ordinary least squares, which corresponds to calculating pay-performance sensitivities at the mean stock ownership. In the OLS regressions, we are able to include fixed effects for each executive $\left(\lambda_{\mathrm{i}}\right)$ in the equation when we estimate pay-performance sensitivities. The fixed effects control for all differences in the average level of compensation across executives in the sample. Only the variations in an executive's pay and her firm's performance relative to their averages over the sample period are used to identify the pay-performance sensitivity. It is extremely important to note that the inclusion of executive fixed effects also controls for any other aspect of the executive or firm that may affect executive compensation, such as the well documented cross-sectional relationship between firm size and its executives' compensation.

Tables 2 and 3 present the median regression results. Median regression minimizes the sum of absolute deviations rather than the sum of squared deviations. ${ }^{8}$ Given the right skewness of the compensation data, the estimated pay-performance sensitivities will be smaller for the median than for the mean. Additionally, since the median is a more robust measure of the center of the data than the mean, the precision of the estimates will also increase. These specifications do not include executive fixed effects. The standard errors are calculated according to the bootstrap procedure in Gould (1992) with twenty replications.

In Table 2, the dependent variable is specified as the change in firm-specific wealth, with and without existing options. The top panel measures performance as the dollar return to shareholders, and the bottom panel uses percentage returns to shareholders. The left two columns estimate the equation for all executives identified as CEOs, and the right two columns estimate the equation for all other executives.

The coefficient on performance in the top panel in the first column shows that for a CEO of a firm with the least variance of stock returns in the sample (i.e., $\mathrm{F}\left(\sigma_{\mathrm{jt}}{ }^{2}\right)=0$ ), firm-specific wealth increases $\$ 27.60$ for every thousand dollar increase in the market value of the firm. The coefficient on the interaction of performance and the CDF of return variance shows that for

\footnotetext{
${ }^{8}$ See Koenker and Bassett (1982). As discussed in Buchinsky (1998), the precise value of the dependent variable in a median regression matters only in determining whether the observation has a positive or negative residual. If the residual is positive (negative), then the dependent variable could increase toward infinity (negative infinity) without affecting the estimated parameters.
} 
executives at firms with more return variance, the pay-performance sensitivity declines substantially. At the maximum variance in the sample (i.e., $\mathrm{F}\left(\sigma_{\mathrm{jt}}{ }^{2}\right)=1$ ), the pay-performance sensitivity is $27.60-26.15=\$ 1.45$ for every thousand dollar increase in market value. At the median variance, the pay-performance sensitivity is $\$ 14.52$ per thousand and is statistically significant. Two features of these results provide strong support for the principal-agent model. First, the coefficient on the interaction of variance and performance, $\gamma_{2}$, is negative and statistically significant. Second, the pay-performance sensitivity at the lowest variance is an order of magnitude greater than the pay-performance sensitivity at the highest variance, showing that the differences in incentives are economically large.

As discussed in Section II, the reporting convention for the value of existing options may exacerbate their sensitivity to firm performance. The next column reports the analogous estimates when the measure of compensation excludes the change in the value of existing options. The coefficient on the interaction term is negative and statistically significant. The ratio of the pay-performance sensitivities at the minimum and maximum variance is about the same as for the change in firm-specific wealth. The median pay-performance sensitivity falls by 55 percent to $\$ 6.59$ per thousand dollars. Because it excludes all incentives from existing options (and over 80 percent of the executives in our sample hold options), this estimate represents a lower bound for the sensitivity of the change in CEO wealth to firm performance.

The next two columns in the top panel of Table 2 present the estimates for executives who are not identified as the CEO of their firm. As in the case of CEOs, the coefficients on the interactions of performance and variance in the dollar returns regressions are all negative and comparable in magnitude to the coefficients on performance. Because the sample size is over three times larger than for CEOs, the coefficients are even more statistically significant. At the median variance, estimated pay-performance sensitivities are about one-fifth the size of those for CEOs. The pay-performance sensitivities at the minimum variance are an order of magnitude greater than the pay-performance sensitivities at the maximum variance. These results show that the principal-agent model is an appropriate characterization of the compensation of other top executives as well as CEOs.

The bottom panel of Table 2 shows that the same basic pattern emerges when performance is measured in percentage returns, but the results are weaker. For CEOs, the estimate on the interaction is negative, though insignificant and small in magnitude. At the 
median variance, a CEO receives $\$ 129,164$ for every percentage point increase in total returns to shareholders. Given the mean and median market values of $\$ 2.9$ billion and $\$ 852$ million in 1995 , this estimate corresponds to pay-performance sensitivities of $\$ 4.45$ and $\$ 15.16$ per thousand when measured in dollar returns. ${ }^{9}$ The number for the median firm is comparable to the estimate of $\$ 14.52$ per thousand in the top panel of the table. For other executives, the coefficients on the interactions are negative and statistically significant.

Our median estimates of the pay-performance sensitivity for CEOs in the top panel of Table 2, \$6.59 to $\$ 14.52$ per thousand, are substantially larger than previous estimates in the literature, such as the $\$ 3.25$ per thousand estimated by Jensen and Murphy (1990a). The discrepancy exists because previous estimates do not explicitly control for the variance of firm performance. In effect, they impose the restriction that $\gamma_{2}=0$. To understand why this restriction leads to lower estimates, note that the median share ownership of CEOs reported in Table $1 \mathrm{~b}$ is about 0.3 percent of their firm. It may seem as if a 0.3 percent share ownership implies that the pay-performance sensitivity would be $\$ 3.00$ per thousand. However, the $\$ 3.00$ per thousand is correct only if the value of holdings in a CEO's own firm is uncorrelated with the variance of firm performance. In fact, CEOs of less risky firms have larger holdings in their own firms. In 1995, for example, the median share of the firm owned by CEOs in firms with less than the median variance was five times as large as the median share owned by CEOs at firms with more than the median variance. ${ }^{10}$

We have also estimated the regressions excluding the terms pertaining to the variance of returns (i.e., imposing the restriction that $\gamma_{2}=\gamma_{3}=0$ ). In those regressions (not reported), the coefficient on firm performance falls from $\$ 14.52$ to $\$ 3.47$ per thousand. The dramatic reduction in the estimate results from forcing the interaction of variance and performance, $\gamma_{2} \mathrm{~F}\left(\sigma_{\mathrm{jt}}{ }^{2}\right) \pi_{\mathrm{jt}}$, into the error term rather than including it as an independent variable. Because $\gamma_{2}$ is actually negative rather than zero, the omitted variable is strongly negatively correlated with the included measure of performance.

As an example, consider the effect of adding two firms to the sample, one with high variance (and therefore low pay-performance sensitivities) and the other with low variance (and therefore high pay-performance sensitivities). Suppose that the CEOs of both firms receive the

\footnotetext{
${ }^{9}$ These estimates are calculated as $4.45=129.164 /(0.01 * 2900)$ and $15.16=129.164 /(0.01 * 852)$.

${ }^{10}$ The comparison is similar for other executives, with those with less than the median variance having three times
} 
same compensation because the high variance firm had good performance and the low variance firm had poor performance. The effect of adding these two observations to a regression that does not control for variance is to lower the estimated pay-performance sensitivity, since the CEO with better performance did not receive higher compensation. In the regression model that we estimate, these observations do not lower the pay-performance sensitivity conditioned on the variance of firm performance. The negative coefficient on the interaction of variance and performance implies that the $\mathrm{CEO}$ at the higher variance firm receives the same compensation only if she delivers higher performance. The similarity in compensation is appropriately ascribed to the differences in the interaction of variance and performance, allowing for a positive effect of performance alone. As a result, the actual pay-performance sensitivity is higher than its estimate in the regression that does not control for variance. This finding suggests that if the principalagent model is the appropriate framework for executive compensation, estimates that ignore the effect of variance on the pay-performance sensitivity will be biased toward zero.

The large pay-performance sensitivities in Table 2 are primarily the result of incentives provided by the executives' ownership of stock and stock options. Table 3 presents the analogous calculations for the flow measures of compensation discussed in Section II. Recall that these measures of compensation are unrelated to the executives' existing stock and option holdings. The pay-performance sensitivities at the median variance show that flow compensation accounts for about 5 percent of the overall estimates in Table 2 for CEOs and 6 percent for other executives. The coefficient on the interaction of performance and variance is negative in each specification. Only one of the twelve estimates is not statistically significant at the one percent level.

In all regressions using flow compensation, the pay-performance sensitivity is significantly positive at the median variance, and in several cases, the sensitivity at the maximum variance is insignificantly different from zero. The gap between CEOs and other executives is much narrower in flow compensation, with CEOs having pay-performance sensitivities about 3 times those of other executives at the median variance in the level and change in flow compensation. Although the pay-performance sensitivities are much smaller, the results in Table 3 show that the decrease in the pay-performance sensitivity with the variance of returns is not just a direct consequence of the distribution of stock and option ownership. The incentives 
provided by flow compensation are also in accordance with the principal-agent model. As an indication of the magnitude of the pay-performance sensitivities, the value of 0.0003 for the percent change in flow compensation for CEOs at the median variance implies that a billion dollar increase in the firm's market value increases a CEO's flow compensation by 30 percent. At the minimum variance, the CEO's flow compensation would increase by 60 percent.

We also estimate equation (2) using ordinary least squares to demonstrate the robustness of our results. The results are reported in Tables 4 and 5. As noted above, in the OLS regressions we are able to include an executive fixed effect. In all cases, heteroskedasticity-robust standard errors are reported beneath the estimated coefficients and pay-performance sensitivities. For the sample of other executives, the standard errors are also calculated to be robust to possible correlations in the errors for different executives within a given firm in each sample year.

The top panel of Table 4 shows that when returns are specified in dollars, the strong confirmation of the principal-agent model in Table 2 is also evident in OLS regressions. The coefficients on the interaction of performance and variance are negative and statistically significant, and the pay-performance sensitivities are an order of magnitude larger at the minimum variance than at the maximum variance. At the median variance, the estimated payperformance sensitivities are substantially larger than their values from the median regressions. The difference is larger for CEOs than for other executives, which is consistent with the presence of more outliers among CEOs than other executives. CEOs are estimated to have mean payperformance sensitivities of $\$ 69.41$ per thousand, compared to $\$ 8.74$ per thousand for other executives.

The results for returns specified in percentages in the bottom panel of Table 4 are consistent with the principal-agent model but less statistically significant. As in the median regressions, the coefficients on the interaction of performance and variance for CEOs are negative but not statistically significant. The results for other executives are strongly supportive of the principal-agent model. For the total change in firm-specific wealth, CEOs receive $\$ 562,480$ per percentage point and other executives receive $\$ 99,316$ for each percentage point of returns to shareholders at the median variance. For the change excluding existing options, CEOs receive $\$ 490,677$ and other executives receive $\$ 68,106$ per percentage point of return at the median variance.

Table 5 reports the OLS regression results for the flow measures of compensation. In all 
cases, the coefficients on the interaction of performance and variance are negative. In all but four cases, they are highly statistically significant and, in all but one case, close to the magnitude of the corresponding coefficient on performance. Compared to the median regressions in Table 3 , the magnitudes of the pay-performance sensitivity at the median variance are lower for flow compensation, higher for the change in flow compensation, and roughly the same for the percentage change in flow compensation.

We have also estimated the regressions in Tables 2 through 5 using measures of risk other than the $\mathrm{CDF}$ of variance. The negative sign and statistical significance of the interaction of performance and risk are robust to the measure of risk used. For example, when we use the variance instead of the $\mathrm{CDF}$ of variance as our measure of risk, the coefficients (standard errors) on the performance and interaction terms are $4.344(0.271)$ and $-0.257(0.085)$, respectively, for the median regressions of "Change in Firm-Specific Wealth" for CEOs using dollar returns. Although the coefficient on the interaction term is again negative and significant, the point estimates for the pay-performance sensitivities are unreliable. The coefficient on performance shows that the pay-performance sensitivity for the minimum variance firm will be about 4.344, which is much lower than even our median estimate of 14.523 in Table 2. The reason for the disparity is that the variance of returns is a skewed variable, giving disproportionate influence in the regression to observations from high variance firms with low pay-performance sensitivities.

To demonstrate this point and to show the robustness of our specification of risk, we also estimated a spline regression based on the quintiles of the distribution of variance. Sorting the firms into quintiles by variance is a more general way of controlling for variance in our estimation. This procedure is equivalent to regressing pay on performance separately for each of the five quintiles. We look directly at the coefficients on performance to determine whether the pay-performance sensitivities differ across the five quintiles. Using the "Change in FirmSpecific Wealth" for CEOs, dollar returns, and median regressions, the pay-performance sensitivities (standard errors) from the lowest to highest variance quintiles are: 30.545 (2.834), 21.161 (2.227), 14.765 (1.382), 8.289 (0.913), 2.365 (0.123). The pay-performance sensitivities are clearly declining as variance increases, and the estimate for the middle quintile of 14.765 is very close to our median estimate of 14.523 from Table $2 .^{11}$

\footnotetext{
${ }^{11}$ While the assumption that the pay-performance sensitivity is linear in the CDF does not affect the point estimate in the median regressions, it has more impact in the OLS regressions. The OLS spline point estimate of the payperformance sensitivity for CEOs in the middle quintile is 40.838 (10.050), compared to the estimate of 69.410 at
} 
Overall, Tables 2 through 5 provide support for the standard principal-agent model, in which pay-performance sensitivities decrease with the variance in the measure of firm performance. There have been two other tests of this prediction in the literature, Garen (1994) and Lambert and Larcker (1987). Garen (1994) regresses the firm-specific estimated payperformance sensitivities of CEOs from Jensen and Murphy (1990b) on a measure of the standard deviation of the excess (percent) return of the firm's stock. The sample period in the Jensen and Murphy (1990b) study was 1974 - 1988. When the standard deviation of returns is not interacted with the log of the firm's assets, Garen (1994) estimates that its coefficient is positive and insignificant. When the standard deviation is interacted with this measure of firm size, its coefficient is estimated to be negative and insignificant. The latter specification is analogous to the first column in the top panel of our Table 2, in which we find that the coefficient on the interaction of performance and variance is negative and highly statistically significant.

Apart from the difference in the sample time periods covered, there are two important differences between his econometric specifications and ours. First, our sample includes approximately three times as many CEOs in each annual cross-section. Second, our specification allows for changes in the variance of performance over time to help identify the coefficient on the interaction term. This yields a total of 4507 separate observations of compensation, performance, and variance in our sample of CEOs. Garen's sample is restricted to only 415 observations (i.e., the single cross-section) because the variance of performance was not included in the regression that estimated Jensen and Murphy's (1990b) firm-specific payperformance sensitivities. It is therefore not surprising that our estimates of the effect of the variance in performance on the pay-performance sensitivity are more consistently negative and are statistically significant.

Lambert and Larcker (1987) use a model in which there are two signals of managerial effort: accounting returns and stock market returns. Using only salary and bonus as their measure of pay, they find weak evidence that the pay-performance sensitivity is influenced by the variance of the return measures. In particular, they find evidence that the pay-performance sensitivity depends on the relative precision of the two measures only when they include observations that have positive weights on both measures of performance (thereby eliminating 
222 of their 370 sample firms). In their full sample, the results are insignificant.

Our point estimates of the pay-performance sensitivity can also be compared to the recent findings of Hall and Liebman (1997), who estimate the distribution of pay-performance sensitivities for a sample of $478 \mathrm{CEOs}$ at large publicly traded corporations. For dollar returns, Hall and Liebman (1997) estimate median and mean values of \$5.29 and \$25 per thousand in 1994 based on their Table VI. We estimate pay-performance sensitivities of \$14.52 and \$69.41 (or \$6.59 and \$58.61 excluding options) over the 1993 to 1996 sample period in the top panels of our Tables 2 and 4. Apart from differences in samples, the major distinction between their specification and ours is that their estimates do not account for the impact of risk on the payperformance sensitivity. In regressions (not reported) in which we omit the variance terms, the estimated pay-performance sensitivities fall to $\$ 3.47$ and $\$ 12.26$ per thousand for the median and mean, respectively. ${ }^{12}$ Failing to account for the variance of the distribution from which a firm's stock return is realized generates a substantial bias toward zero. It is worth reiterating, however, that the validity of the principal-agent model is better judged by the comparative static relationship between variance and the pay-performance sensitivity than the average level of the pay-performance sensitivity itself.

\section{The Relative Performance Evaluation Results}

In this section, we extend the analysis to consider the relative performance evaluation model. Suppose, following Holmström and Milgrom (1987), that in addition to firm performance, contracts can be written on another variable that is correlated with the noise component of firm performance. This variable is assumed to be uninformative about the executive's action. An example would be the performance of other firms in the industry or in the market as a whole under the assumption that the actions of one executive do not affect the performance of other firms in her industry. ${ }^{13}$ Random shocks to firm performance are likely to be correlated across firms. This correlation can be used to decrease the risk faced by an executive and improve her contract. Denote this additional random variable or signal as $\theta$, where $\theta \sim \mathrm{N}\left[0, \sigma_{\theta}{ }^{2}\right]$ and has a correlation coefficient of $\rho$ with $\varepsilon$. The manager's compensation contract is given by $\mathrm{w}=\alpha_{0}+\alpha_{1} \pi+\alpha_{2} \theta$. The optimal performance related components of the contract for

\footnotetext{
${ }^{12}$ The dependent variable in these regressions is the "Change in Firm-Specific Wealth."

${ }^{13}$ In Aggarwal and Samwick (1997), we argue that this assumption is likely to be false due to strategic interactions
} 
a risk averse manager are:

$$
\begin{aligned}
\alpha_{1}^{*} & =\frac{1}{1+r k \sigma_{\varepsilon}^{2}\left(1-\rho^{2}\right)} . \\
\alpha_{2}^{*} & =-\alpha_{1}^{*} \rho \frac{\sigma_{\varepsilon}}{\sigma_{\theta}}
\end{aligned} .
$$

Relative performance evaluation occurs in the sense that the performance of the rest of the industry is used to reduce the variance of the firm shock in the optimal contract. The optimal contract puts a negative weight, $\alpha_{2}$, on industry performance. ${ }^{14}$ Defining $\sigma_{\varepsilon}{ }^{2}\left(1-\rho^{2}\right)$ to be the variance of the idiosyncratic shock to the firm's performance, one comparative static prediction of the model is that the weight on own-firm performance $\left(\alpha_{1}\right)$ is decreasing in the idiosyncratic variance of firm returns. Further, the ratio of the weight on industry performance to the weight on own-firm performance $\left(\alpha_{2} / \alpha_{1}\right)$ is negative and decreasing in the correlation of firm and industry returns, decreasing in the variance of firm returns, and increasing in the variance of industry returns.

There is one additional point to be made about these contracts when the additional variable is industry or market returns. If these returns are specified as percentage returns, then the weight on industry performance in the optimal contract is:

$$
\alpha_{2}^{*}=-\alpha_{1}^{*} \rho \frac{\sigma_{\varepsilon}}{\sigma_{\theta}}=-\alpha_{1}^{*} \beta
$$

$\beta$ is the firm's stock beta from the CAPM measured relative to either the industry or the market, depending on the benchmark used. The ratio of the weight on industry performance to own-firm performance, $\alpha_{2} / \alpha_{1}$, is equal to $-\beta$. Thus, beta will be a sufficient index for the amount of relative performance evaluation that occurs in the Holmström-Milgrom model. Firms with high covariance with their industry or firms in industries with little variance will do more relative performance evaluation. Note, however, that beta itself does not directly affect $\alpha_{1}$.

There is some confusion about the role of beta in relative performance evaluation in the literature. Garen (1994) argues that firms with high betas should give less performance-based compensation (i.e., lower $\alpha_{1}$ ). This will only be true if, holding constant the correlation coefficient and industry variance, beta is high because firm variance is high. However, if beta is 
high because the correlation between firm and industry returns is high, holding constant firm and industry variance, then high betas could yield more performance-based compensation (i.e., higher $\alpha_{1}$ ). Therefore, tests based on whether a higher beta reduces performance-based compensation are inconclusive with respect to the relative performance evaluation model. Garen (1994) also argues that salary-based compensation should increase with beta, by the same logic. However, salary-based compensation could either decrease or increase with beta without implying anything about the relative performance evaluation model. Garen (1994) finds that both salary-based compensation and stock- or performance-based compensation decrease with a firm's beta. These findings do not reject a relative performance evaluation model, nor do they provide any degree of confirmation.

Instead, we directly test the following restriction implied by the relative performance evaluation model:

$$
\frac{\partial\left(\alpha_{2}^{*} / \alpha_{1}^{*}\right)}{\partial \beta}=-1
$$

We test two versions of this restriction. The first is that this derivative is literally equal to -1 . This test corresponds exactly to the strong-form test of the relative performance evaluation model in Janakiraman, Lambert, and Larcker (1992). The second test is simply that the derivative is negative, which is clearly a much weaker restriction. It allows for the possibility that there may be other factors that determine the relative weights on own and industry performance that are unrelated to the effort-insurance tradeoff.

In order to test the relationship between pay and relative performance, we modify our existing specification in two ways. The first is that the own-firm pay-performance sensitivity $\left(\alpha_{1}\right)$ depends on $\sigma_{\varepsilon}^{2}\left(1-\rho^{2}\right)$, the variance of the idiosyncratic shock to the firm's performance. We construct the empirical CDF of the idiosyncratic variance and denote its value for firm $j$ in year $t$ by $\mathrm{G}_{\mathrm{jt}}$. The second modification is that the regression must include terms for the industry payperformance sensitivity, $\alpha_{2}$. Since the theoretical result is that $\alpha_{2}=-\alpha_{1} \beta_{\mathrm{jt}}$, four variables are needed to capture the effect of industry performance. The first variable is industry performance itself, $\theta_{\mathrm{jt}}$. The second is industry performance interacted with the CDF of idiosyncratic variance, $\mathrm{G}_{\mathrm{jt}} \theta_{\mathrm{jt}}$, because $\alpha_{1}$ varies with idiosyncratic variance. The third is industry performance interacted with beta, $\beta_{\mathrm{jt}} \theta_{\mathrm{jt}}$. The fourth is industry performance interacted with both beta and idiosyncratic 
variance, $\mathrm{G}_{\mathrm{jt}} \beta_{\mathrm{jt}} \theta_{\mathrm{jt}}$. These last two variables are included because the relationship between $\beta_{\mathrm{jt}}$ and $\alpha_{1}$ is multiplicative. The econometric specification that we estimate is:

$$
\begin{gathered}
w_{i j t}=\delta_{0}+\delta_{1} \pi{ }_{j t}+\delta_{2} G_{j t} \pi{ }_{j t}+\delta_{3} \theta_{j t}+\delta_{4} G_{j t} \theta_{j t}+\delta_{5} \beta_{j t} \theta_{j t}+\delta_{6} G_{j t} \beta_{j t} \theta_{j t}+ \\
\delta_{7} G_{j t}+\delta_{8} \beta_{j t}+\delta_{9} G_{j t} \beta_{j t}+\lambda_{i}+\mu_{t}+\varepsilon_{i t} .
\end{gathered}
$$

The own and industry pay-performance sensitivities for an executive at firm $j$ are therefore:

$$
\begin{aligned}
& \frac{\partial w_{i j t}}{\partial \pi_{j t}}=\alpha_{1}=\delta_{1}+\delta_{2} G_{j t} \\
& \frac{\partial w_{i j t}}{\partial \theta_{j t}}=\alpha_{2}=\delta_{3}+\delta_{4} G_{j t}+\delta_{5} \beta_{j t}+\delta_{6} G_{j t} \beta_{j t} .
\end{aligned}
$$

For simplicity, we suppress the firm and executive subscripts on the pay-performance sensitivities. The remaining variables in the regression-- $\mathrm{G}_{\mathrm{jt}}, \beta_{\mathrm{jt}}$, and $\mathrm{G}_{\mathrm{jt}} \beta_{\mathrm{jt}}$--are included to control for any differences in the level of compensation in the cross-section that may be due to variance, beta, or their interaction. As in the tests of the principal-agent model in Section II, the specification includes year effects $\left(\mu_{\mathrm{t}}\right)$ in both median and OLS regressions and executive fixed effects $\left(\lambda_{\mathrm{i}}\right)$ in the OLS regressions.

The two tests of the relative performance evaluation model are Wald tests based on:

$$
\frac{\partial\left(\alpha_{2} / \alpha_{1}\right)}{\partial \beta_{j t}}=\frac{\delta_{5}+\delta_{6} G_{j t}}{\delta_{1}+\delta_{2} G_{j t}} .
$$

The first null hypothesis (H1) is that this derivative is equal to zero. We view this test as the key test of relative performance evaluation because it is a comparative static prediction that does not imply a terribly strong restriction on the data. Any tendency to filter out the common component of shocks will reject the null hypothesis in favor of the relative performance evaluation model. The second null hypothesis $(\mathrm{H} 2)$ is that the derivative is equal to negative one, as implied by the relative performance evaluation model. If relative performance evaluation is but one of several factors that determine the weight on industry performance, then this null could be rejected even if there were some use of relative performance evaluation.

Industry performance $\left(\theta_{\mathrm{jt}}\right)$ can be defined as narrowly as the 4-digit SIC level or as broadly as the market as a whole. We have done the analysis at each level, and the results are similar across levels. We report the results for the 2-digit level because at narrower definitions of the industry, some firms in our sample become monopolies within their industries and 
therefore do not have separate industry returns. For regressions that use percentage returns as the measure of performance, $\theta_{\mathrm{jt}}$ is the dollar-weighted average total return to shareholders for all sample firms in the 2-digit SIC excluding firm $j$. For regressions that use dollar returns as the measure of performance, $\theta_{\mathrm{jt}}$ is this average return multiplied by firm $j$ 's market value at the beginning of year $t$. This reflects the dollar returns that firm $j$ 's shareholders would have received had the firm achieved the average industry percent return.

In order to test for relative performance evaluation, we would ideally like to have data on the executive's entire portfolio of investments to determine whether her wealth is affected by the performance of her industry. Since we do not have such data, we cannot determine if relative performance evaluation is present in the incentives generated by the executive's holdings of stock or stock options in her own firm. We are therefore able to test for relative performance evaluation using only the three measures of flow compensation.

Table 6 presents median regressions using dollar returns as the measure of performance. The top panel presents the coefficient estimates and their standard errors. The bottom panel presents the own and industry pay-performance sensitivities and the derivative of $\left(\alpha_{2} / \alpha_{1}\right)$ with respect to the stock beta. Beneath each statistic is the p-value in brackets for the test of the relevant null hypothesis. Each statistic is evaluated at the median variance of the idiosyncratic component of the own-firm performance (i.e., $\mathrm{G}_{\mathrm{jt}}=0.5$ ) and at the expected value of $\beta_{\mathrm{jt}}=1$.

In all specifications, the own-firm pay-performance sensitivity is positive and significant. The own-firm pay-performance sensitivities are very close in magnitude to the corresponding values in Table 3, which tested the principal-agent model. For example, the value of 0.702 for the flow compensation of CEOs is slightly lower than the value of 0.732 estimated in Table 3. For flow compensation for both CEOs and other executives, the industry pay-performance sensitivity is positive and insignificant. For both the change and percent change in flow compensation for both CEOs and other executives, the industry pay-performance sensitivities are negative and generally significant. These results provide mixed support for the relative performance evaluation model.

The tests of the derivative of $\left(\alpha_{2} / \alpha_{1}\right)$ with respect to the stock beta are presented in the next row. For flow compensation for both CEOs and other executives, the derivative of $\left(\alpha_{2} / \alpha_{1}\right)$ with respect to the stock beta is negative. For change in flow compensation and percent change in flow compensation, the derivatives are positive for CEOs and negative for other executives. 
The p-values in the row labeled $\mathrm{H} 1$ show that in no case is the derivative significantly different from zero. These results provide no support for the relative performance evaluation model.

The second test based on the derivative, $\mathrm{H} 2$, uses the value of negative one predicted by the relative performance evaluation model as the null hypothesis. A low p-value for this test would imply that the derivative is significantly different from negative one and would provide evidence against the relative performance evaluation model. In five of the specifications the pvalue is below 0.05 , formally rejecting the relative performance evaluation model on the basis of this test.

Table 7 presents median regressions using percent returns as the measure of performance. The own-firm pay-performance sensitivities are positive and significant. The industry payperformance sensitivities are positive and significant for flow compensation and generally negative and insignificant for the other measures of compensation. The tests of the derivative of $\left(\alpha_{2} / \alpha_{1}\right)$ with respect to beta are unambiguous. The point estimates are generally positive and always insignificantly different from zero. They are in all cases significantly different from negative one. The median regressions in Tables 6 and 7 provide consistent evidence against the relative performance evaluation model.

Table 8 contains the results using OLS and dollar returns as the measure of performance. In all regressions, the own-firm pay-performance sensitivities are positive and close in magnitude to the corresponding values in the top panel of Table 5, which tested the principalagent model. The own-firm pay-performance sensitivities are significant in only three of the six specifications. The industry pay-performance sensitivity is not significant in any specification, and is positive for the dollar change in flow compensation and negative for the level and percent change in flow compensation.

The tests of the derivative of $\left(\alpha_{2} / \alpha_{1}\right)$ with respect to beta are presented in the next row. In all cases, the point estimate of the derivative is positive, in contrast to the negative derivative predicted by the theory. In no case is the derivative significantly different from zero. These results provide evidence against the relative performance evaluation model. In only one case is the derivative significantly different from negative one, although all of the p-values are below 0.2. The confidence intervals around the point estimates are sufficiently large to include both zero and negative one. Therefore, it is not possible to formally reject the relative performance evaluation model on the basis of $\mathrm{H} 2$. 
The OLS results in Table 9 use percent returns as the measure of firm and industry performance. They similarly fail to support the relative performance evaluation model. As in Table 8, the own-firm pay-performance sensitivities are positive. In these regressions, they are statistically significant. Each point estimate is somewhat larger than its counterpart in the bottom panel of Table 5. The estimates of the industry pay-performance sensitivity are negative in all cases, but in no cases are the estimates statistically significant. The point estimates for the derivative of $\left(\alpha_{2} / \alpha_{1}\right)$ with respect to beta are sometimes positive and sometimes negative but never significantly different from zero. In the cases of the percent change in flow compensation to CEOs and the level of flow compensation to other executives, the derivatives are significantly different from negative one. The results using percent returns as the measure of performance do not provide support for the relative performance evaluation model.

Janakiraman, Lambert, and Larcker (1992) find comparable results in their analysis of relative performance evaluation. Specifically, in their strong form test of the relative performance evaluation model (which corresponds to our H2), they find no evidence of complete filtering of the industry component of firm performance. They also examine whether the industry pay-performance sensitivity is negative. They find that it is positive and significant when performance is measured using accounting returns and negative and significant when performance is measured using stock returns. In the latter case, the industry performance variable adds little explanatory power to their compensation regressions.

The lack of evidence in support of the relative performance evaluation model has remained a puzzle in the literature on executive compensation. Although it may seem that our strong evidence in favor of the principal-agent model would deepen the puzzle, there are reasons why firms would optimally choose not to use relative performance evaluation to filter out common components of shocks to performance. While the use of relative performance evaluation may improve the contract with respect to aspects of firm performance that the executive cannot control (i.e., the common shock), it may worsen the contract with respect to aspects of firm performance that the executive can control, such as pricing decisions.

In Aggarwal and Samwick (1997), we show that strategic interactions among firms in an industry can explain the lack of relative performance evaluation in executive compensation. When managers can be compensated based on their own and their industry performance, the need to soften product market competition generates an optimal compensation contract that 
places a positive weight on both own and industry profits. The negative weight on industry performance implied by the relative performance evaluation model would give the executive an incentive to price too aggressively in the product market, thereby hurting firm profits. We find empirical support for this proposition by showing that executives in more competitive industries, where the consequences of strategic interactions are most important, have compensation contracts that place greater positive weights on industry performance relative to the weight on own-firm performance.

\section{Conclusion}

Much of the literature on executive compensation relies on the intuition of the principalagent model. In particular, there is a presumption that managers will have large payperformance sensitivities to align their interests with those of their shareholders. The empirical literature has debated whether average pay-performance sensitivities are small (Jensen and Murphy (1990a)) or large (Hall and Liebman (1997)). We demonstrate that focusing on the average level fails to appreciate the heterogeneity in pay-performance sensitivities. This heterogeneity can be used to explore the key cross-sectional prediction of the principal-agent model: an executive's pay-performance sensitivity will be decreasing in the riskiness of the firm's performance.

We test this prediction directly using a large sample of top executives at the biggest publicly traded corporations in the United States. We find that the pay-performance sensitivities of both CEOs and other executives are decreasing in the variance of their firms' stock returns for a variety of measures of compensation. We show that the variance of a firm's stock returns is an important variable in pay-performance regressions and that omitting it leads to downward biased estimates of the pay-performance sensitivity. In general, we find that executives in companies with the lowest variance have pay-performance sensitivities that are an order of magnitude greater than executives in companies with the highest variance. We further show that payperformance sensitivities that do not condition on firm variance dramatically understate the true pay-performance sensitivities that do condition on variance.

We also consider an extension of the principal-agent model to relative performance evaluation. The relative performance evaluation model has several testable predictions. First, the industry pay-performance sensitivity is negative. This prediction has been studied in several 
previous papers, with mixed results. This debate is similar to the debate about the average size of the own-firm pay-performance sensitivity in that it does not exploit the cross-sectional predictions to test the model. Second, the ratio of the industry pay-performance sensitivity to the own-firm pay-performance sensitivity is decreasing in a firm's stock beta. We find minimal evidence that the industry pay-performance sensitivity is negative and no evidence that the ratio of the industry pay-performance sensitivity to the own-firm pay-performance sensitivity is decreasing in a firm's stock beta. These results suggest that relative performance evaluation considerations are not incorporated into executive compensation contracts. In Aggarwal and Samwick (1997), we provide a theoretical explanation and a test for why it may not be optimal to incorporate relative performance evaluation into compensation contracts due to strategic interactions between managers at rival firms. The relative performance evaluation results in this paper and our earlier work are mutually consistent.

Our results support the principal-agent model of executive compensation. Previous studies of the average level of the pay-performance sensitivity cannot determine whether observed pay-performance sensitivities are optimal because such a conclusion depends critically on unobserved parameters. Our comparative static approach suggests that principal-agent considerations are incorporated into executive compensation contracts. Theoretical models based on the principal-agent problem between shareholders and managers have robust empirical support and are an essential element of a complete theory of corporate governance. 


\section{References}

Aggarwal, Rajesh K., and Samwick, Andrew A. "Executive Compensation, Relative Performance Evaluation, and Strategic Competition: Theory and Evidence." Manuscript. Hanover, NH: Dartmouth College, 1997.

Antle, Rick, and Smith, Abbie. "An Empirical Investigation of the Relative Performance Evaluation of Corporate Executives.” Journal of Accounting Research 24 (Spring 1986): 1-39.

Barro, Jason R., and Barro, Robert J. "Pay, Performance, and Turnover of Bank CEOs.” Journal of Labor Economics 8 (October 1990): 448-81.

Berle, Adolf, and Means, Gardiner. The Modern Corporation and Private Property. New York: Macmillan, 1932.

Buchinsky, Moshe. "Recent Advances in Quantile Regression Models: A Practical Guideline for Empirical Research.” Journal of Human Resources 33 (Winter 1998): 88-126.

Garen, John. "Executive Compensation and Principal-Agent Theory." Journal of Political Economy 102 (December 1994): 1175-99.

Gibbons, Robert, and Murphy, Kevin J. "Relative Performance Evaluation for Chief Executive Officers.” Industrial and Labor Relations Review 43 (February 1990): 30-S - 51-S.

Gould, W. W. "Quantile Regression with Bootstrapped Standard Errors.” Stata Technical Bulletin 9 (1992): 19-21.

Hall, Brian, and Liebman, Jeffrey. “Are CEOs Really Paid Like Bureaucrats?” Working Paper no. 6213. Cambridge, MA: National Bureau of Economic Research, October 1997.

Haubrich, Joseph G. "Risk Aversion, Performance Pay, and the Principal-Agent Problem." Journal of Political Economy 102 (April 1994): 258-76.

Holmström, Bengt. "Moral Hazard and Observability." Bell Journal of Economics 10 (Spring 1979): 74-91.

Holmström, Bengt. "Moral Hazard in Teams." Bell Journal of Economics 13 (Summer 1982): 324-40.

Holmström, Bengt, and Milgrom, Paul. "Aggregation and Linearity in the Provision of Intertemporal Incentives.” Econometrica 55 (March 1987): 303-28.

Janakiraman, Surya; Lambert, Richard; and Larcker, David. "An Empirical Investigation of the Relative Performance Evaluation Hypothesis.” Journal of Accounting Research 30 (Spring 1992): 53-69. 
Jensen, Michael, and Murphy, Kevin J. "Performance Pay and Top Management Incentives." Journal of Political Economy 98 (April 1990): 225-64. (a)

Jensen, Michael, and Murphy, Kevin J. "CEO Incentives-It's Not How Much You Pay, But How." Harvard Business Review 68 (May-June 1990): 138-53. (b)

Joh, Sung Wook. "Strategic Managerial Incentive Compensation in Japan: Relative Performance Evaluation and Product Market Collusion." Manuscript. Albany, NY: State University of New York, May 1996.

Koenker, Roger, and Bassett, G. Jr. "Robust Tests for Heteroscedasticity Based on Regression Quantiles.” Econometrica 50 (January 1982): 43-61.

Lambert, Richard, and Larcker, David. "An Analysis of the Use of Accounting and Market Measures of Performance in Executive Compensation Contracts." Journal of Accounting Research 25 (Supplement 1987): 85-125.

Shleifer, Andrei, and Vishny, Robert. “A Survey of Corporate Governance.” Journal of Finance 52 (June 1997): 737-83.

Standard and Poor's. $\underline{S \& P}$ Compustat ExecuComp: The Executive Compensation Database. Englewood, CO: McGraw-Hill, November 1995. 
Table 1a

Measures of Executive Compensation, 1995

\begin{tabular}{|c|c|c|c|c|c|c|c|c|}
\hline & & Chief Exe & ive Officer & & & Other & ecutives & \\
\hline & Mean & Median & Minimum & Maximum & Mean & Median & Minimum & Maximum \\
\hline $\begin{array}{l}\text { Flow } \\
\text { Comp. }\end{array}$ & $\begin{array}{c}2,313 \\
{[n=1275]}\end{array}$ & 1,359 & 0 & 65,580 & $\begin{array}{c}939 \\
{[\mathrm{n}=5522]}\end{array}$ & 565 & 0 & 34,733 \\
\hline $\begin{array}{l}\text { Change in } \\
\text { Flow }\end{array}$ & $\begin{array}{c}182 \\
{[n=1176]}\end{array}$ & 41 & $-29,823$ & 35,781 & $\begin{array}{c}69 \\
{[n=4355]}\end{array}$ & 25 & $-54,522$ & 27,275 \\
\hline $\begin{array}{l}\text { Change in } \\
\text { Log(Flow) }\end{array}$ & $\begin{array}{c}0.062 \\
{[n=1174]}\end{array}$ & 0.051 & -3.218 & 2.956 & $\begin{array}{c}0.073 \\
{[n=4353]}\end{array}$ & 0.061 & -4.620 & 5.486 \\
\hline $\begin{array}{l}\text { Change in } \\
\text { Firm- } \\
\text { Specific } \\
\text { Wealth }\end{array}$ & $\begin{array}{c}24,225 \\
{[\mathrm{n}=1214]}\end{array}$ & 3,096 & $-114,407$ & $5,619,255$ & $\begin{array}{c}4,201 \\
{[n=3966]}\end{array}$ & 1,074 & $-117,766$ & $1,107,114$ \\
\hline $\begin{array}{l}\text { Excluding } \\
\text { Existing } \\
\text { Options }\end{array}$ & $\begin{array}{c}21,097 \\
{[\mathrm{n}=1215]}\end{array}$ & 2,016 & $-110,905$ & $5,619,255$ & $\begin{array}{c}3,104 \\
{[n=3988]}\end{array}$ & 753 & $-117,766$ & $1,107,114$ \\
\hline
\end{tabular}

Notes:

1) All dollar amounts are in thousands of 1995 dollars.

2) The number of observations used for each sample and compensation measure is reported in brackets beneath the mean amount of compensation.

Table $1 b$

Ownership of Stock and Stock Options, 1995

\begin{tabular}{|c|c|c|c|c|c|c|c|c|}
\hline & \multicolumn{4}{|c|}{ Chief Executive Officers } & \multicolumn{4}{|c|}{ Other Executives } \\
\hline & \multirow{2}{*}{$\begin{array}{c}\text { Percent } \\
\text { who Own }\end{array}$} & \multicolumn{2}{|c|}{ Conditional } & \multirow[b]{2}{*}{ Maximum } & \multirow{2}{*}{$\begin{array}{c}\text { Percent } \\
\text { Who Own }\end{array}$} & \multicolumn{2}{|c|}{ Conditional } & \multirow[b]{2}{*}{ Maximum } \\
\hline & & Mean & Median & & & Mean & Median & \\
\hline $\begin{array}{l}\text { Wealth in } \\
\text { Firm Stock }\end{array}$ & $97.96 \%$ & 65,361 & 4,641 & $16,600,000$ & $93.61 \%$ & 8,066 & 648 & $2,707,011$ \\
\hline $\begin{array}{l}\text { Share of } \\
\text { Firm Owned }\end{array}$ & & $2.98 \%$ & $0.31 \%$ & $63.23 \%$ & & $0.44 \%$ & $0.05 \%$ & $43.38 \%$ \\
\hline $\begin{array}{l}\text { Options on } \\
\text { Firm Stock }\end{array}$ & $81.25 \%$ & 7,294 & 2,158 & 317,880 & $82.39 \%$ & 2,177 & 669 & 127,325 \\
\hline $\begin{array}{l}\text { Current } \\
\text { Option } \\
\text { Grants }\end{array}$ & $68.87 \%$ & 1,234 & 510 & 41,011 & $72.41 \%$ & 393 & 166 & 22,861 \\
\hline
\end{tabular}

Notes:

1) All dollar amounts are in thousands of 1995 dollars.

2) Current option grants are valued according to the Black-Scholes formula, as described in Standard and Poor's (1995). 
Table 1c

Distributions of Real Returns to Shareholders, 1993 - 1996

\begin{tabular}{|c|c|c|c|c|c|}
\hline Percentiles & $\begin{array}{l}\text { Percent Returns } \\
\text { to Shareholders }\end{array}$ & $\begin{array}{l}\text { Dollar Returns } \\
\text { to Shareholders }\end{array}$ & $\begin{array}{c}\text { Standard } \\
\text { Deviation of } \\
\text { Percent Returns }\end{array}$ & $\begin{array}{c}\text { Std. Dev. of } \\
\text { Idiosyncratic } \\
\text { Percent Returns }\end{array}$ & $\begin{array}{l}\text { Industry Beta } \\
\text { (2-digit SIC) }\end{array}$ \\
\hline & \multicolumn{2}{|c|}{ Annual Returns } & \multicolumn{3}{|c|}{ Monthly Returns } \\
\hline 0 & $-97.38 \%$ & $-\$ 18,755$ & 2.73 & 0.52 & -0.660 \\
\hline 10 & -25.55 & -265 & 4.99 & 3.81 & 0.483 \\
\hline 20 & -12.67 & -87 & 5.83 & 4.68 & 0.643 \\
\hline 30 & -4.63 & -25 & 6.52 & 5.31 & 0.764 \\
\hline 40 & 2.53 & 15 & 7.31 & 6.03 & 0.862 \\
\hline 50 & 9.91 & 61 & 8.07 & 6.76 & 0.965 \\
\hline 60 & 17.26 & 124 & 9.01 & 7.65 & 1.058 \\
\hline 70 & 26.10 & 242 & 10.06 & 8.70 & 1.158 \\
\hline 80 & 37.42 & 515 & 11.54 & 10.11 & 1.287 \\
\hline 90 & 57.33 & 1,311 & 13.77 & 12.27 & 1.526 \\
\hline 100 & 475.71 & 60,990 & 32.06 & 31.54 & 3.360 \\
\hline Mean & 14.72 & 483 & 8.82 & 7.52 & 0.989 \\
\hline Source & \multicolumn{2}{|c|}{ S \& P ExecuComp } & \multicolumn{3}{|c|}{ CRSP } \\
\hline
\end{tabular}

Notes:

1) Dollar returns are reported in millions of constant 1995 dollars.

2) Standard deviations and betas of returns are calculated over the five years preceding the year in which the firm is observed in the ExecuComp sample. 
Table 2

Median Regression Estimates of Pay-Performance Sensitivities for Measures of Firm-Specific Wealth, 1993 - 1996

\begin{tabular}{|c|c|c|c|c|}
\hline & \multicolumn{2}{|c|}{ Chief Executive Officers } & \multicolumn{2}{|c|}{ Other Executives } \\
\hline & Change in Wealth & $\begin{array}{c}\text { Excluding } \\
\text { Existing Options }\end{array}$ & Change in Wealth & $\begin{array}{c}\text { Excluding } \\
\text { Existing Options }\end{array}$ \\
\hline Dollar Returns & \multicolumn{4}{|c|}{ Coefficients from Median Regressions } \\
\hline$\gamma_{1}$ Performance & $\begin{array}{l}27.596 \\
(1.983)\end{array}$ & $\begin{array}{l}12.550 \\
(0.766)\end{array}$ & $\begin{array}{c}6.008 \\
(0.140)\end{array}$ & $\begin{array}{l}2.145 \\
(0.091)\end{array}$ \\
\hline $\begin{array}{l}\gamma_{2} \text { Performance } * \\
\text { CDF of Variance }\end{array}$ & $\begin{array}{l}-26.147 \\
(2.093)\end{array}$ & $\begin{array}{l}-11.920 \\
(0.837)\end{array}$ & $\begin{array}{l}-5.427 \\
(0.154)\end{array}$ & $\begin{array}{l}-1.923 \\
(0.101)\end{array}$ \\
\hline$\gamma_{3}$ CDF of Variance & $\begin{array}{l}2710 \\
(180)\end{array}$ & $\begin{array}{l}2327 \\
(110)\end{array}$ & $\begin{array}{l}1134 \\
(26)\end{array}$ & $\begin{array}{c}1052 \\
(27)\end{array}$ \\
\hline & \multicolumn{4}{|c|}{ Estimated Pay-Performance Sensitivities } \\
\hline $\begin{array}{l}\alpha_{1} \text { estimated at: } \\
\text { Median } \\
\text { Variance }\end{array}$ & $\begin{array}{l}14.523 \\
(0.955)\end{array}$ & $\begin{array}{c}6.590 \\
(0.356)\end{array}$ & $\begin{array}{l}3.295 \\
(0.065)\end{array}$ & $\begin{array}{l}1.184 \\
(0.041)\end{array}$ \\
\hline $\begin{array}{l}\text { Maximum } \\
\text { Variance }\end{array}$ & $\begin{array}{c}1.450 \\
(0.287)\end{array}$ & $\begin{array}{c}0.630 \\
(0.127)\end{array}$ & $\begin{array}{c}0.582 \\
(0.027)\end{array}$ & $\begin{array}{c}0.222 \\
(0.016)\end{array}$ \\
\hline Percent Returns & \multicolumn{4}{|c|}{ Coefficients from Median Regressions } \\
\hline$\gamma_{1}$ Performance & $\begin{array}{l}133.748 \\
(7.992)\end{array}$ & $\begin{array}{l}69.997 \\
(7.842)\end{array}$ & $\begin{array}{l}43.900 \\
(1.869)\end{array}$ & $\begin{array}{l}24.471 \\
(1.060)\end{array}$ \\
\hline $\begin{array}{l}\gamma_{2} \text { Performance * } \\
\text { CDF of Variance }\end{array}$ & $\begin{array}{c}-9.168 \\
(24.096)\end{array}$ & $\begin{array}{c}-8.781 \\
(17.416)\end{array}$ & $\begin{array}{l}-24.130 \\
(2.934)\end{array}$ & $\begin{array}{l}-20.470 \\
(1.326)\end{array}$ \\
\hline$\gamma_{3}$ CDF of Variance & $\begin{array}{c}39 \\
(241)\end{array}$ & $\begin{array}{c}-3 \\
(159)\end{array}$ & $\begin{array}{r}-105 \\
(35)\end{array}$ & $\begin{array}{l}-178 \\
(27)\end{array}$ \\
\hline & \multicolumn{4}{|c|}{ Estimated Pay-Performance Sensitivities } \\
\hline $\begin{array}{l}\alpha_{1} \text { estimated at: } \\
\text { Median } \\
\text { Variance }\end{array}$ & $\begin{array}{l}129.164 \\
(5.739)\end{array}$ & $\begin{array}{l}65.606 \\
(2.681)\end{array}$ & $\begin{array}{l}31.835 \\
(0.768)\end{array}$ & $\begin{array}{l}14.236 \\
(0.463)\end{array}$ \\
\hline $\begin{array}{l}\text { Maximum } \\
\text { Variance }\end{array}$ & $\begin{array}{l}124.580 \\
(17.097)\end{array}$ & $\begin{array}{c}61.216 \\
(10.225)\end{array}$ & $\begin{array}{l}19.771 \\
(1.411)\end{array}$ & $\begin{array}{c}4.001 \\
(0.430)\end{array}$ \\
\hline Observations & 4507 & 4586 & 14594 & 14888 \\
\hline
\end{tabular}

Notes:

1) Each regression includes year effects.

2) Bootstrapped standard errors based on 20 replications are in parentheses below each estimate.

3) Compensation is measured in thousands and dollar returns are measured in millions of 1995 dollars. Percent returns are measured in percentage points.

4) The pay-performance sensitivity is $\alpha_{1}=\gamma_{1}+\mathrm{F}\left(\sigma^{2}\right)^{*} \gamma_{2}$. 
Table 3

Median Regression Estimates of Pay-Performance Sensitivities for Measures of Flow Compensation, 1993 - 1996

\begin{tabular}{|c|c|c|c|c|c|c|}
\hline & \multicolumn{3}{|c|}{ Chief Executive Officers } & \multicolumn{3}{|c|}{ Other Executives } \\
\hline & $\begin{array}{l}\text { Flow } \\
\text { Comp. }\end{array}$ & $\begin{array}{l}\text { Change } \\
\text { in Flow }\end{array}$ & $\begin{array}{l}\% \text { Change } \\
\text { in Flow }\end{array}$ & $\begin{array}{l}\text { Flow } \\
\text { Comp. }\end{array}$ & $\begin{array}{l}\text { Change } \\
\text { in Flow }\end{array}$ & $\begin{array}{l}\text { \% Change } \\
\text { in Flow }\end{array}$ \\
\hline Dollar Returns & \multicolumn{6}{|c|}{ Coefficients from Median Regressions } \\
\hline$\gamma_{1}$ Performance & $\begin{array}{l}1.224 \\
(0.248)\end{array}$ & $\begin{array}{c}0.811 \\
(0.112)\end{array}$ & $\begin{array}{c}0.0006 \\
(0.00004)\end{array}$ & $\begin{array}{c}0.319 \\
(0.030)\end{array}$ & $\begin{array}{c}0.233 \\
(0.019)\end{array}$ & $\begin{array}{c}0.0004 \\
(0.00003)\end{array}$ \\
\hline $\begin{array}{l}\gamma_{2} \text { Performance } * \\
\text { CDF of Variance }\end{array}$ & $\begin{array}{l}-0.986 \\
(0.290)\end{array}$ & $\begin{array}{l}-0.757 \\
(0.122)\end{array}$ & $\begin{array}{c}-0.0006 \\
(0.00004)\end{array}$ & $\begin{array}{l}-0.234 \\
(0.032)\end{array}$ & $\begin{array}{l}-0.216 \\
(0.022)\end{array}$ & $\begin{array}{c}-0.0004 \\
(0.00003)\end{array}$ \\
\hline$\gamma_{3}$ CDF of Variance & $\begin{array}{l}2197 \\
(69)\end{array}$ & $\begin{array}{l}160 \\
(37)\end{array}$ & $\begin{array}{c}0.0229 \\
(0.0131)\end{array}$ & $\begin{array}{l}937 \\
(13)\end{array}$ & $\begin{array}{l}47 \\
(5)\end{array}$ & $\begin{array}{c}0.0033 \\
(0.0086)\end{array}$ \\
\hline & \multicolumn{6}{|c|}{ Estimated Pay-Performance Sensitivities } \\
\hline $\begin{array}{l}\alpha_{1} \text { estimated at: } \\
\text { Median } \\
\text { Variance }\end{array}$ & $\begin{array}{c}0.732 \\
(0.108)\end{array}$ & $\begin{array}{c}0.432 \\
(0.053)\end{array}$ & $\begin{array}{c}0.0003 \\
(0.00002)\end{array}$ & $\begin{array}{c}0.201 \\
(0.015)\end{array}$ & $\begin{array}{c}0.125 \\
(0.008)\end{array}$ & $\begin{array}{c}0.0002 \\
(0.00001)\end{array}$ \\
\hline $\begin{array}{l}\text { Maximum } \\
\text { Variance }\end{array}$ & $\begin{array}{c}0.239 \\
(0.064)\end{array}$ & $\begin{array}{c}0.053 \\
(0.022)\end{array}$ & $\begin{array}{c}0.000002 \\
(0.000003)\end{array}$ & $\begin{array}{c}0.084 \\
(0.005)\end{array}$ & $\begin{array}{c}0.017 \\
(0.004)\end{array}$ & $\begin{array}{c}0.0000003 \\
(0.0000015)\end{array}$ \\
\hline Percent Returns & \multicolumn{6}{|c|}{ Coefficients from Median Regressions } \\
\hline$\gamma_{1}$ Performance & $\begin{array}{l}18.892 \\
(1.760)\end{array}$ & $\begin{array}{l}5.536 \\
(0.528)\end{array}$ & $\begin{array}{c}0.0040 \\
(0.0007)\end{array}$ & $\begin{array}{l}6.796 \\
(0.461)\end{array}$ & $\begin{array}{l}1.959 \\
(0.090)\end{array}$ & $\begin{array}{c}0.0033 \\
(0.0002)\end{array}$ \\
\hline $\begin{array}{l}\gamma_{2} \text { Performance }{ }^{*} \\
\text { CDF of Variance }\end{array}$ & $\begin{array}{l}-19.120 \\
(2.266)\end{array}$ & $\begin{array}{l}-3.869 \\
(0.688)\end{array}$ & $\begin{array}{l}-0.0019 \\
(0.0011)\end{array}$ & $\begin{array}{l}-7.123 \\
(0.535)\end{array}$ & $\begin{array}{l}-1.476 \\
(0.158)\end{array}$ & $\begin{array}{l}-0.0021 \\
(0.0003)\end{array}$ \\
\hline$\gamma_{3}$ CDF of Variance & $\begin{array}{l}-306 \\
(76)\end{array}$ & $\begin{array}{l}-26 \\
(20)\end{array}$ & $\begin{array}{l}-0.0281 \\
(0.0264)\end{array}$ & $\begin{array}{l}-150 \\
(11)\end{array}$ & $\begin{array}{l}-2 \\
(5)\end{array}$ & $\begin{array}{c}0.0042 \\
(0.0076)\end{array}$ \\
\hline & \multicolumn{6}{|c|}{ Estimated Pay-Performance Sensitivities } \\
\hline $\begin{array}{l}\alpha_{1} \text { estimated at: } \\
\text { Median } \\
\text { Variance }\end{array}$ & $\begin{array}{c}9.332 \\
(0.753)\end{array}$ & $\begin{array}{l}3.601 \\
(0.263)\end{array}$ & $\begin{array}{c}0.0030 \\
(0.0002)\end{array}$ & $\begin{array}{c}3.234 \\
(0.207)\end{array}$ & $\begin{array}{l}1.221 \\
(0.040)\end{array}$ & $\begin{array}{c}0.0023 \\
(0.0001)\end{array}$ \\
\hline $\begin{array}{l}\text { Maximum } \\
\text { Variance }\end{array}$ & $\begin{array}{l}-0.228 \\
(0.778)\end{array}$ & $\begin{array}{l}1.667 \\
(0.309)\end{array}$ & $\begin{array}{c}0.0020 \\
(0.0005)\end{array}$ & $\begin{array}{l}-0.327 \\
(0.128)\end{array}$ & $\begin{array}{c}0.482 \\
(0.087)\end{array}$ & $\begin{array}{c}0.0013 \\
(0.0002)\end{array}$ \\
\hline Observations & 4982 & 4496 & 4490 & 21428 & 16419 & 16414 \\
\hline
\end{tabular}

Notes:

1) Each regression includes year effects.

2) Bootstrapped standard errors based on 20 replications are in parentheses below each estimate.

3) Compensation is measured in thousands and dollar returns are measured in millions of 1995 dollars. Percent returns are measured in percentage points.

4) The pay-performance sensitivity is $\alpha_{1}=\gamma_{1}+F\left(\sigma^{2}\right) * \gamma_{2}$. 
Table 4

OLS Estimates of Pay-Performance Sensitivities for Measures of Firm-Specific Wealth, 1993 - 1996

\begin{tabular}{|c|c|c|c|c|}
\hline & \multicolumn{2}{|c|}{ Chief Executive Officers } & \multicolumn{2}{|c|}{ Other Executives } \\
\hline & Change in Wealth & $\begin{array}{c}\text { Excluding } \\
\text { Existing Options }\end{array}$ & Change in Wealth & $\begin{array}{c}\text { Excluding } \\
\text { Existing Options }\end{array}$ \\
\hline Dollar Returns & \multicolumn{4}{|c|}{ Coefficients from OLS Regressions } \\
\hline$\gamma_{1}$ Performance & $\begin{array}{l}129.916 \\
(41.130)\end{array}$ & $\begin{array}{l}108.269 \\
(40.877)\end{array}$ & $\begin{array}{l}16.207 \\
(2.364)\end{array}$ & $\begin{array}{l}10.837 \\
(2.476)\end{array}$ \\
\hline $\begin{array}{l}\gamma_{2} \text { Performance } * \\
\text { CDF of Variance }\end{array}$ & $\begin{array}{l}-121.011 \\
(41.851)\end{array}$ & $\begin{array}{l}-99.323 \\
(41.671)\end{array}$ & $\begin{array}{l}-14.936 \\
(2.479)\end{array}$ & $\begin{array}{l}-10.119 \\
(2.591)\end{array}$ \\
\hline$\gamma_{3}$ CDF of Variance & $\begin{array}{c}50763 \\
(36354)\end{array}$ & $\begin{array}{c}47201 \\
(35162)\end{array}$ & $\begin{array}{c}-677 \\
(3905)\end{array}$ & $\begin{array}{l}-4247 \\
(4829)\end{array}$ \\
\hline & \multicolumn{4}{|c|}{ Estimated Pay-Performance Sensitivities } \\
\hline $\begin{array}{l}\alpha_{1} \text { estimated at: } \\
\text { Median } \\
\text { Variance }\end{array}$ & $\begin{array}{c}69.410 \\
(20.352)\end{array}$ & $\begin{array}{c}58.608 \\
(20.200)\end{array}$ & $\begin{array}{c}8.739 \\
(1.140)\end{array}$ & $\begin{array}{c}5.777 \\
(1.195)\end{array}$ \\
\hline $\begin{array}{l}\text { Maximum } \\
\text { Variance }\end{array}$ & $\begin{array}{c}8.905 \\
(3.539)\end{array}$ & $\begin{array}{c}8.946 \\
(3.663)\end{array}$ & $\begin{array}{c}1.271 \\
(0.292)\end{array}$ & $\begin{array}{c}0.718 \\
(0.291)\end{array}$ \\
\hline Percent Returns & \multicolumn{4}{|c|}{ Coefficients from OLS Regressions } \\
\hline$\gamma_{1}$ Performance & $\begin{array}{c}716.420 \\
(242.525)\end{array}$ & $\begin{array}{c}625.691 \\
(241.992)\end{array}$ & $\begin{array}{l}156.089 \\
(34.737)\end{array}$ & $\begin{array}{l}111.845 \\
(34.093)\end{array}$ \\
\hline $\begin{array}{l}\gamma_{2} \text { Performance } * \\
\text { CDF of Variance }\end{array}$ & $\begin{array}{l}-307.881 \\
(367.170)\end{array}$ & $\begin{array}{l}-270.027 \\
(361.565)\end{array}$ & $\begin{array}{l}-113.547 \\
(43.597)\end{array}$ & $\begin{array}{l}-87.478 \\
(42.946)\end{array}$ \\
\hline$\gamma_{3}$ CDF of Variance & $\begin{array}{l}-54182 \\
(27697)\end{array}$ & $\begin{array}{l}-63947 \\
(28581)\end{array}$ & $\begin{array}{l}-1775 \\
(2866)\end{array}$ & $\begin{array}{l}-2076 \\
(2629)\end{array}$ \\
\hline & \multicolumn{4}{|c|}{ Estimated Pay-Performance Sensitivities } \\
\hline $\begin{array}{l}\alpha_{1} \text { estimated at: } \\
\text { Median } \\
\text { Variance }\end{array}$ & $\begin{array}{c}562.480 \\
(107.994)\end{array}$ & $\begin{array}{c}490.677 \\
(108.815)\end{array}$ & $\begin{array}{c}99.316 \\
(14.258)\end{array}$ & $\begin{array}{c}68.106 \\
(13.908)\end{array}$ \\
\hline $\begin{array}{l}\text { Maximum } \\
\text { Variance }\end{array}$ & $\begin{array}{c}408.539 \\
(178.646)\end{array}$ & $\begin{array}{c}355.664 \\
(174.602)\end{array}$ & $\begin{array}{c}42.542 \\
(12.258)\end{array}$ & $\begin{array}{c}24.367 \\
(12.117)\end{array}$ \\
\hline Observations & 4507 & 4586 & 14594 & 14888 \\
\hline
\end{tabular}

Notes:

1) Each regression includes year effects and executive fixed effects.

2) Heteroskedasticity robust standard errors are in parentheses below each estimate. For regressions on the sample of other executives, the standard errors are robust to correlation among executives at the same firm in each year.

3) Compensation is measured in thousands and dollar returns are measured in millions of 1995 dollars. Percent returns are measured in percentage points.

4) The pay-performance sensitivity is $\alpha_{1}=\gamma_{1}+\mathrm{F}\left(\sigma^{2}\right) * \gamma_{2}$. 
Table 5

OLS Estimates of Pay-Performance Sensitivities for Measures of Flow Compensation, 1993 - 1996

\begin{tabular}{|c|c|c|c|c|c|c|}
\hline & \multicolumn{3}{|c|}{ Chief Executive Officers } & \multicolumn{3}{|c|}{ Other Executives } \\
\hline & $\begin{array}{l}\text { Flow } \\
\text { Comp. }\end{array}$ & $\begin{array}{l}\text { Change } \\
\text { in Flow }\end{array}$ & $\begin{array}{l}\text { \% Change } \\
\text { in Flow }\end{array}$ & $\begin{array}{l}\text { Flow } \\
\text { Comp. }\end{array}$ & $\begin{array}{l}\text { Change } \\
\text { in Flow }\end{array}$ & $\begin{array}{c}\text { \% Change } \\
\text { in Flow }\end{array}$ \\
\hline Dollar Returns & \multicolumn{6}{|c|}{ Coefficients from OLS Regressions } \\
\hline$\gamma_{1}$ Performance & $\begin{array}{c}0.886 \\
(0.445)\end{array}$ & $\begin{array}{l}2.025 \\
(0.644)\end{array}$ & $\begin{array}{c}0.0006 \\
(0.0001)\end{array}$ & $\begin{array}{c}0.174 \\
(0.122)\end{array}$ & $\begin{array}{c}0.470 \\
(0.170)\end{array}$ & $\begin{array}{c}0.0004 \\
(0.0001)\end{array}$ \\
\hline $\begin{array}{l}\gamma_{2} \text { Performance } * \\
\text { CDF of Variance }\end{array}$ & $\begin{array}{l}-0.748 \\
(0.463)\end{array}$ & $\begin{array}{l}-1.978 \\
(0.669)\end{array}$ & $\begin{array}{l}-0.0006 \\
(0.0001)\end{array}$ & $\begin{array}{l}-0.129 \\
(0.126)\end{array}$ & $\begin{array}{l}-0.424 \\
(0.171)\end{array}$ & $\begin{array}{l}-0.0004 \\
(0.0001)\end{array}$ \\
\hline$\gamma_{3} \mathrm{CDF}$ of Variance & $\begin{array}{c}4379 \\
(2208)\end{array}$ & $\begin{array}{c}1722 \\
(2093)\end{array}$ & $\begin{array}{l}-0.467 \\
(0.340)\end{array}$ & $\begin{array}{c}748 \\
(422)\end{array}$ & $\begin{array}{c}18 \\
(394)\end{array}$ & $\begin{array}{l}-0.127 \\
(0.235)\end{array}$ \\
\hline & \multicolumn{6}{|c|}{ Estimated Pay-Performance Sensitivities } \\
\hline $\begin{array}{l}\alpha_{1} \text { estimated at: } \\
\text { Median } \\
\text { Variance }\end{array}$ & $\begin{array}{c}0.512 \\
(0.216)\end{array}$ & $\begin{array}{l}1.036 \\
(0.313)\end{array}$ & $\begin{array}{c}0.0003 \\
(0.00005)\end{array}$ & $\begin{array}{c}0.110 \\
(0.060)\end{array}$ & $\begin{array}{c}0.258 \\
(0.086)\end{array}$ & $\begin{array}{c}0.0002 \\
(0.00003)\end{array}$ \\
\hline $\begin{array}{l}\text { Maximum } \\
\text { Variance }\end{array}$ & $\begin{array}{c}0.138 \\
(0.052)\end{array}$ & $\begin{array}{c}0.047 \\
(0.072)\end{array}$ & $\begin{array}{l}-0.000002 \\
(0.000007)\end{array}$ & $\begin{array}{c}0.045 \\
(0.013)\end{array}$ & $\begin{array}{c}0.046 \\
(0.021)\end{array}$ & $\begin{array}{c}0.000002 \\
(0.000005)\end{array}$ \\
\hline Percent Returns & \multicolumn{6}{|c|}{ Coefficients from OLS Regressions } \\
\hline$\gamma_{1}$ Performance & $\begin{array}{c}7.472 \\
(3.952)\end{array}$ & $\begin{array}{l}9.487 \\
(5.554)\end{array}$ & $\begin{array}{c}0.0051 \\
(0.0010)\end{array}$ & $\begin{array}{l}3.538 \\
(0.973)\end{array}$ & $\begin{array}{l}5.702 \\
(1.586)\end{array}$ & $\begin{array}{c}0.0046 \\
(0.0008)\end{array}$ \\
\hline $\begin{array}{l}\gamma_{2} \text { Performance }{ }^{*} \\
\text { CDF of Variance }\end{array}$ & $\begin{array}{l}-6.899 \\
(5.184)\end{array}$ & $\begin{array}{l}-3.713 \\
(7.544)\end{array}$ & $\begin{array}{l}-0.0036 \\
(0.0014)\end{array}$ & $\begin{array}{l}-3.960 \\
(1.185)\end{array}$ & $\begin{array}{l}-5.205 \\
(1.945)\end{array}$ & $\begin{array}{l}-0.0039 \\
(0.0010)\end{array}$ \\
\hline$\gamma_{3} \mathrm{CDF}$ of Variance & $\begin{array}{l}-1922 \\
(1059)\end{array}$ & $\begin{array}{l}-1331 \\
(1267)\end{array}$ & $\begin{array}{c}0.068 \\
(0.220)\end{array}$ & $\begin{array}{l}-274 \\
(270)\end{array}$ & $\begin{array}{l}-264 \\
(395)\end{array}$ & $\begin{array}{l}-0.071 \\
(0.169)\end{array}$ \\
\hline & \multicolumn{6}{|c|}{ Estimated Pay-Performance Sensitivities } \\
\hline $\begin{array}{l}\alpha_{1} \text { estimated at: } \\
\text { Median } \\
\text { Variance }\end{array}$ & $\begin{array}{c}4.022 \\
(1.702)\end{array}$ & $\begin{array}{l}7.631 \\
(2.447)\end{array}$ & $\begin{array}{c}0.0033 \\
(0.0004)\end{array}$ & $\begin{array}{l}1.558 \\
(0.433)\end{array}$ & $\begin{array}{l}3.099 \\
(0.740)\end{array}$ & $\begin{array}{c}0.0027 \\
(0.0003)\end{array}$ \\
\hline $\begin{array}{l}\text { Maximum } \\
\text { Variance }\end{array}$ & $\begin{array}{c}0.573 \\
(1.901)\end{array}$ & $\begin{array}{c}5.774 \\
(3.095)\end{array}$ & $\begin{array}{c}0.0015 \\
(0.0006)\end{array}$ & $\begin{array}{c}-0.422 \\
(0.360)\end{array}$ & $\begin{array}{c}0.497 \\
(0.687)\end{array}$ & $\begin{array}{c}0.0007 \\
(0.0004)\end{array}$ \\
\hline Observations & 4982 & 4496 & 4490 & 21428 & 16419 & 16414 \\
\hline
\end{tabular}

Notes:

1) Each regression includes year effects and executive fixed effects.

2) Heteroskedasticity robust standard errors are in parentheses below each estimate. For regressions on the sample of other executives, the standard errors are robust to correlation among executives at the same firm in each year.

3) Compensation is measured in thousands and dollar returns are measured in millions of 1995 dollars. Percent returns are measured in percentage points.

4) The pay-performance sensitivity is $\alpha_{1}=\gamma_{1}+F\left(\sigma^{2}\right) * \gamma_{2}$. 
Table 6

Tests of Relative Performance Evaluation at the 2-digit SIC Level, Dollar Returns, Median Regressions, 1993 - 1996

\begin{tabular}{|c|c|c|c|c|c|c|}
\hline & \multicolumn{3}{|c|}{$\begin{array}{l}\text { Chief Executive Officers } \\
\end{array}$} & \multicolumn{3}{|c|}{ Other Executives } \\
\hline & $\begin{array}{l}\text { Flow } \\
\text { Comp. }\end{array}$ & $\begin{array}{l}\text { Change } \\
\text { in Flow }\end{array}$ & $\begin{array}{l}\text { \% Change } \\
\text { in Flow }\end{array}$ & $\begin{array}{l}\text { Flow } \\
\text { Comp. }\end{array}$ & $\begin{array}{l}\text { Change } \\
\text { in Flow }\end{array}$ & $\begin{array}{l}\text { \% Change } \\
\text { in Flow }\end{array}$ \\
\hline & \multicolumn{6}{|c|}{ Coefficients from Median Regressions } \\
\hline$\delta_{1}$ Performance & $\begin{array}{c}1.340 \\
(0.246)\end{array}$ & $\begin{array}{c}0.823 \\
(0.142)\end{array}$ & $\begin{array}{c}0.0006 \\
(0.0001)\end{array}$ & $\begin{array}{c}0.359 \\
(0.047)\end{array}$ & $\begin{array}{c}0.251 \\
(0.017)\end{array}$ & $\begin{array}{c}0.0004 \\
(0.00003)\end{array}$ \\
\hline $\begin{array}{l}\delta_{2} \text { Performance } * \\
\text { CDF of Variance }\end{array}$ & $\begin{array}{l}-1.276 \\
(0.313)\end{array}$ & $\begin{array}{l}-0.782 \\
(0.165)\end{array}$ & $\begin{array}{l}-0.0006 \\
(0.0001)\end{array}$ & $\begin{array}{l}-0.332 \\
(0.053)\end{array}$ & $\begin{array}{l}-0.241 \\
(0.019)\end{array}$ & $\begin{array}{c}-0.0004 \\
(0.00004)\end{array}$ \\
\hline $\begin{array}{l}\delta_{3} \text { Industry } \\
\text { Performance }\end{array}$ & $\begin{array}{c}0.838 \\
(0.563)\end{array}$ & $\begin{array}{l}-0.408 \\
(0.334)\end{array}$ & $\begin{array}{l}-0.0002 \\
(0.0002)\end{array}$ & $\begin{array}{c}0.224 \\
(0.109)\end{array}$ & $\begin{array}{l}-0.068 \\
(0.048)\end{array}$ & $\begin{array}{l}-0.0002 \\
(0.0001)\end{array}$ \\
\hline $\begin{array}{l}\delta_{4} \text { Industry Perf. } * \\
\text { CDF of Variance }\end{array}$ & $\begin{array}{l}-0.847 \\
(0.631)\end{array}$ & $\begin{array}{c}0.416 \\
(0.355)\end{array}$ & $\begin{array}{c}0.0002 \\
(0.0002)\end{array}$ & $\begin{array}{l}-0.224 \\
(0.105)\end{array}$ & $\begin{array}{c}0.080 \\
(0.057)\end{array}$ & $\begin{array}{c}0.0002 \\
(0.0001)\end{array}$ \\
\hline $\begin{array}{l}\delta_{5} \text { Industry Perf. * } \\
\text { Industry Beta }\end{array}$ & $\begin{array}{l}-0.878 \\
(0.702)\end{array}$ & $\begin{array}{c}0.069 \\
(0.351)\end{array}$ & $\begin{array}{l}0.000003 \\
(0.0002)\end{array}$ & $\begin{array}{l}-0.241 \\
(0.101)\end{array}$ & $\begin{array}{l}-0.026 \\
(0.055)\end{array}$ & $\begin{array}{l}-0.00002 \\
(0.00006)\end{array}$ \\
\hline $\begin{array}{c}\delta_{6} \text { Industry Perf. * } \\
\text { CDF * Beta }\end{array}$ & $\begin{array}{l}1.133 \\
(0.756)\end{array}$ & $\begin{array}{l}-0.042 \\
(0.365)\end{array}$ & $\begin{array}{c}-0.000005 \\
(0.0002)\end{array}$ & $\begin{array}{c}0.329 \\
(0.098)\end{array}$ & $\begin{array}{c}0.025 \\
(0.062)\end{array}$ & $\begin{array}{c}0.00001 \\
(0.00006)\end{array}$ \\
\hline$\delta_{7} \mathrm{CDF}$ of Variance & $\begin{array}{l}1890 \\
(257)\end{array}$ & $\begin{array}{c}151 \\
(109)\end{array}$ & $\begin{array}{c}0.0680 \\
(0.0713)\end{array}$ & $\begin{array}{l}753 \\
(38)\end{array}$ & $\begin{array}{c}22 \\
(13)\end{array}$ & $\begin{array}{l}-0.0060 \\
(0.0251)\end{array}$ \\
\hline$\delta_{8}$ Industry Beta & $\begin{array}{c}2 \\
(82)\end{array}$ & $\begin{array}{l}-14 \\
(32)\end{array}$ & $\begin{array}{l}-0.0054 \\
(0.0379)\end{array}$ & $\begin{array}{l}-37 \\
(10)\end{array}$ & $\begin{array}{l}-6 \\
(4)\end{array}$ & $\begin{array}{l}-0.0024 \\
(0.0171)\end{array}$ \\
\hline$\delta_{9} \mathrm{CDF} *$ Beta & $\begin{array}{c}177 \\
(240)\end{array}$ & $\begin{array}{c}33 \\
(109)\end{array}$ & $\begin{array}{l}-0.0283 \\
(0.0707)\end{array}$ & $\begin{array}{l}144 \\
(38)\end{array}$ & $\begin{array}{c}28 \\
(14)\end{array}$ & $\begin{array}{c}0.0180 \\
(0.0244)\end{array}$ \\
\hline $\begin{array}{c}\alpha_{1} \text { Own Firm } \\
\text { Sensitivity }\end{array}$ & $\begin{array}{c}0.702 \\
{[0.000]}\end{array}$ & $\begin{array}{c}\text { Co } \\
0.431 \\
{[0.000]}\end{array}$ & $\begin{array}{l}\text { tive Statics } \\
0.0003 \\
{[0.000]}\end{array}$ & $\begin{array}{c}\text { P-values } \\
0.193 \\
{[0.000]}\end{array}$ & $\begin{array}{c}\text { ckets }] \\
0.131 \\
{[0.000]}\end{array}$ & $\begin{array}{l}0.0002 \\
{[0.000]}\end{array}$ \\
\hline $\begin{array}{ll}\alpha_{2} & \text { Industry } \\
& \text { Sensitivity }\end{array}$ & $\begin{array}{c}0.104 \\
{[0.589]}\end{array}$ & $\begin{array}{l}-0.153 \\
{[0.016]}\end{array}$ & $\begin{array}{l}-0.0001 \\
{[0.085]}\end{array}$ & $\begin{array}{c}0.036 \\
{[0.256]}\end{array}$ & $\begin{array}{c}-0.042 \\
{[0.002]}\end{array}$ & $\begin{array}{l}-0.0001 \\
{[0.000]}\end{array}$ \\
\hline $\begin{array}{l}\text { Derivative of }\left(\alpha_{2} / \alpha_{1}\right) \\
\text { H1: Zero } \\
\text { H2: Negative one }\end{array}$ & $\begin{array}{l}-0.444 \\
{[0.351]} \\
{[0.242]}\end{array}$ & $\begin{array}{c}0.110 \\
{[0.784]} \\
{[0.006]}\end{array}$ & $\begin{array}{l}0.0036 \\
{[0.991]} \\
{[0.002]}\end{array}$ & $\begin{array}{l}-0.393 \\
{[0.135]} \\
{[0.021]}\end{array}$ & $\begin{array}{l}-0.106 \\
{[0.595]} \\
{[0.000]}\end{array}$ & $\begin{array}{l}-0.055 \\
{[0.695]} \\
{[0.000]}\end{array}$ \\
\hline Observations & 4620 & 4172 & 4166 & 19868 & 15291 & 15286 \\
\hline
\end{tabular}

Notes:

1) Each regression includes year effects.

2) Bootstrapped standard errors based on 20 replications are in parentheses below each estimate.

3) Compensation is measured in thousands and dollar returns are measured in millions of 1995 dollars.

4) The pay-performance sensitivities are $\alpha_{1}=\delta_{1}+0.5 * \delta_{2}$ and $\alpha_{2}=\delta_{3}+0.5 * \delta_{4}+1 * \delta_{5}+0.5 * 1 * \delta_{6}$. 
Table 7

Tests of Relative Performance Evaluation at the 2-digit SIC Level, Percent Returns, Median Regressions, 1993 - 96

\begin{tabular}{|c|c|c|c|c|c|c|}
\hline & \multicolumn{3}{|c|}{ Chief Executive Officers } & \multicolumn{3}{|c|}{ Other Executives } \\
\hline & $\begin{array}{l}\text { Flow } \\
\text { Comp. }\end{array}$ & $\begin{array}{l}\text { Change } \\
\text { in Flow }\end{array}$ & $\begin{array}{c}\text { \% Change } \\
\text { in Flow }\end{array}$ & $\begin{array}{l}\text { Flow } \\
\text { Comp. }\end{array}$ & $\begin{array}{l}\text { Change } \\
\text { in Flow }\end{array}$ & $\begin{array}{c}\text { \% Change } \\
\text { in Flow }\end{array}$ \\
\hline Percent Returns & \multicolumn{6}{|c|}{ Coefficients from Median Regressions } \\
\hline$\delta_{1}$ Performance & $\begin{array}{l}16.594 \\
(2.767)\end{array}$ & $\begin{array}{l}5.914 \\
(0.879)\end{array}$ & $\begin{array}{c}0.0038 \\
(0.0005)\end{array}$ & $\begin{array}{c}6.657 \\
(0.568)\end{array}$ & $\begin{array}{l}2.229 \\
(0.131)\end{array}$ & $\begin{array}{c}0.0037 \\
(0.0002)\end{array}$ \\
\hline $\begin{array}{l}\delta_{2} \text { Performance } * \\
\text { CDF of Variance }\end{array}$ & $\begin{array}{l}-16.175 \\
(3.224)\end{array}$ & $\begin{array}{l}-4.193 \\
(1.231)\end{array}$ & $\begin{array}{l}-0.0015 \\
(0.0009)\end{array}$ & $\begin{array}{l}-6.867 \\
(0.612)\end{array}$ & $\begin{array}{l}-1.829 \\
(0.213)\end{array}$ & $\begin{array}{l}-0.0025 \\
(0.0004)\end{array}$ \\
\hline $\begin{array}{l}\delta_{3} \text { Industry } \\
\text { Performance }\end{array}$ & $\begin{array}{l}15.951 \\
(9.432)\end{array}$ & $\begin{array}{l}-0.872 \\
(2.302)\end{array}$ & $\begin{array}{c}0.0011 \\
(0.0022)\end{array}$ & $\begin{array}{c}8.637 \\
(1.380)\end{array}$ & $\begin{array}{l}-0.422 \\
(0.483)\end{array}$ & $\begin{array}{l}-0.0012 \\
(0.0008)\end{array}$ \\
\hline $\begin{array}{l}\delta_{4} \text { Industry Perf. * } \\
\text { CDF of Variance }\end{array}$ & $\begin{array}{l}-26.806 \\
(12.243)\end{array}$ & $\begin{array}{l}-0.025 \\
(3.210)\end{array}$ & $\begin{array}{l}-0.0022 \\
(0.0032)\end{array}$ & $\begin{array}{l}-12.685 \\
(1.919)\end{array}$ & $\begin{array}{c}0.437 \\
(0.669)\end{array}$ & $\begin{array}{c}0.0016 \\
(0.0012)\end{array}$ \\
\hline $\begin{array}{l}\delta_{5} \text { Industry Perf. } * \\
\text { Industry Beta }\end{array}$ & $\begin{array}{c}2.045 \\
(11.066)\end{array}$ & $\begin{array}{c}1.074 \\
(2.824)\end{array}$ & $\begin{array}{l}-0.0010 \\
(0.0019)\end{array}$ & $\begin{array}{l}-3.508 \\
(1.291)\end{array}$ & $\begin{array}{c}0.426 \\
(0.501)\end{array}$ & $\begin{array}{c}0.0003 \\
(0.0008)\end{array}$ \\
\hline $\begin{array}{c}\delta_{6} \text { Industry Perf. * } \\
\text { CDF } * \text { Beta }\end{array}$ & $\begin{array}{c}4.451 \\
(12.583)\end{array}$ & $\begin{array}{l}-1.137 \\
(3.702)\end{array}$ & $\begin{array}{c}0.0012 \\
(0.0029)\end{array}$ & $\begin{array}{c}7.013 \\
(1.682)\end{array}$ & $\begin{array}{l}-0.198 \\
(0.665)\end{array}$ & $\begin{array}{l}-0.0003 \\
(0.0012)\end{array}$ \\
\hline$\delta_{7} \mathrm{CDF}$ of Variance & $\begin{array}{c}787 \\
(218)\end{array}$ & $\begin{array}{c}89 \\
(54)\end{array}$ & $\begin{array}{c}0.0615 \\
(0.0639)\end{array}$ & $\begin{array}{l}360 \\
(40)\end{array}$ & $\begin{array}{c}5 \\
(10)\end{array}$ & $\begin{array}{l}-0.0227 \\
(0.0183)\end{array}$ \\
\hline$\delta_{8}$ Industry Beta & $\begin{array}{l}1445 \\
(208)\end{array}$ & $\begin{array}{l}116 \\
(37)\end{array}$ & $\begin{array}{c}0.0514 \\
(0.0252)\end{array}$ & $\begin{array}{l}685 \\
(30)\end{array}$ & $\begin{array}{l}26 \\
(5)\end{array}$ & $\begin{array}{c}0.0071 \\
(0.0122)\end{array}$ \\
\hline$\delta_{9} \mathrm{CDF} *$ Beta & $\begin{array}{l}-1399 \\
(265)\end{array}$ & $\begin{array}{l}-126 \\
(52)\end{array}$ & $\begin{array}{l}-0.0832 \\
(0.0655)\end{array}$ & $\begin{array}{l}-712 \\
(39)\end{array}$ & $\begin{array}{r}-19 \\
(8)\end{array}$ & $\begin{array}{c}0.0079 \\
(0.0188)\end{array}$ \\
\hline $\begin{array}{c}\alpha_{1} \text { Own Firm } \\
\text { Sensitivity }\end{array}$ & $\begin{array}{c}8.506 \\
{[0.000]}\end{array}$ & $\begin{array}{l}\text { Cor } \\
3.818 \\
{[0.000]}\end{array}$ & $\begin{array}{c}\text { tive Statics } \\
0.0031 \\
{[0.000]}\end{array}$ & $\begin{array}{c}\text { P-values } \\
3.224 \\
{[0.000]}\end{array}$ & $\begin{array}{l}\text { ckets] } \\
1.315 \\
{[0.000]}\end{array}$ & $\begin{array}{l}0.0024 \\
{[0.000]}\end{array}$ \\
\hline $\begin{array}{ll}\alpha_{2} & \text { Industry } \\
& \text { Sensitivity }\end{array}$ & $\begin{array}{c}6.818 \\
{[0.031]}\end{array}$ & $\begin{array}{l}-0.379 \\
{[0.639]}\end{array}$ & $\begin{array}{l}-0.0004 \\
{[0.328]}\end{array}$ & $\begin{array}{c}2.293 \\
{[0.000]}\end{array}$ & $\begin{array}{c}0.124 \\
{[0.241]}\end{array}$ & $\begin{array}{l}-0.0002 \\
{[0.264]}\end{array}$ \\
\hline $\begin{array}{l}\text { Derivative of }\left(\alpha_{2} / \alpha_{1}\right) \\
\text { H1: Zero } \\
\text { H2: Negative one }\end{array}$ & $\begin{array}{c}0.502 \\
{[0.481]} \\
{[0.035]}\end{array}$ & $\begin{array}{c}0.132 \\
{[0.713]} \\
{[0.002]}\end{array}$ & $\begin{array}{l}-0.150 \\
{[0.643]} \\
{[0.009]}\end{array}$ & $\begin{array}{l}-0.0003 \\
{[0.999]} \\
{[0.000]}\end{array}$ & $\begin{array}{c}0.248 \\
{[0.210]} \\
{[0.000]}\end{array}$ & $\begin{array}{c}0.050 \\
{[0.683]} \\
{[0.000]}\end{array}$ \\
\hline Observations & 4620 & 4172 & 4166 & 19868 & 15291 & 15286 \\
\hline
\end{tabular}

Notes:

1) Each regression includes year effects.

2) Bootstrapped standard errors based on 20 replications are in parentheses below each estimate.

3) Compensation is measured in thousands of 1995 dollars. Percent returns are measured in percentage points.

4) The pay-performance sensitivities are $\alpha_{1}=\delta_{1}+0.5 * \delta_{2}$ and $\alpha_{2}=\delta_{3}+0.5 * \delta_{4}+1 * \delta_{5}+0.5 * 1 * \delta_{6}$. 
Table 8

Tests of Relative Performance Evaluation at the 2-digit SIC Level, Dollar Returns, OLS Regressions, 1993 - 1996

\begin{tabular}{|c|c|c|c|c|c|c|}
\hline & \multicolumn{3}{|c|}{ Chief Executive Officers } & \multicolumn{3}{|c|}{ Other Executives } \\
\hline & $\begin{array}{l}\text { Flow } \\
\text { Comp. }\end{array}$ & $\begin{array}{l}\text { Change } \\
\text { in Flow }\end{array}$ & $\begin{array}{l}\% \text { Change } \\
\text { in Flow }\end{array}$ & $\begin{array}{l}\text { Flow } \\
\text { Comp. }\end{array}$ & $\begin{array}{l}\text { Change } \\
\text { in Flow }\end{array}$ & $\begin{array}{l}\% \text { Change } \\
\text { in Flow }\end{array}$ \\
\hline Dollar Returns & \multicolumn{6}{|c|}{ Coefficients from OLS Regressions } \\
\hline & $\begin{array}{c}0.958 \\
(0.822)\end{array}$ & $\begin{array}{l}1.730 \\
(1.159)\end{array}$ & $\begin{array}{l}\text { efficients fr } \\
0.0006 \\
(0.0001)\end{array}$ & $\begin{array}{l}\text { LS Regr } \\
0.227 \\
(0.152)\end{array}$ & $\begin{array}{c}0.521 \\
(0.242)\end{array}$ & $\begin{array}{c}0.0005 \\
(0.0001)\end{array}$ \\
\hline $\begin{array}{l}\delta_{2} \text { Performance } * \\
\text { CDF of Variance }\end{array}$ & $\begin{array}{c}-0.842 \\
(0.815)\end{array}$ & $\begin{array}{l}-1.690 \\
(1.157)\end{array}$ & $\begin{array}{l}-0.0006 \\
(0.0001)\end{array}$ & $\begin{array}{l}-0.194 \\
(0.156)\end{array}$ & $\begin{array}{l}-0.469 \\
(0.244)\end{array}$ & $\begin{array}{l}-0.0005 \\
(0.0001)\end{array}$ \\
\hline $\begin{array}{l}\delta_{3} \text { Industry } \\
\text { Performance }\end{array}$ & $\begin{array}{l}-3.615 \\
(1.801)\end{array}$ & $\begin{array}{l}-1.532 \\
(2.143)\end{array}$ & $\begin{array}{l}-0.0006 \\
(0.0004)\end{array}$ & $\begin{array}{l}-0.836 \\
(0.484)\end{array}$ & $\begin{array}{l}-0.559 \\
(0.806)\end{array}$ & $\begin{array}{l}-0.0002 \\
(0.0004)\end{array}$ \\
\hline $\begin{array}{c}\delta_{4} \text { Industry Perf. * } \\
\text { CDF of Variance }\end{array}$ & $\begin{array}{c}3.922 \\
(1.854)\end{array}$ & $\begin{array}{c}1.911 \\
(2.262)\end{array}$ & $\begin{array}{c}0.0006 \\
(0.0004)\end{array}$ & $\begin{array}{c}0.937 \\
(0.529)\end{array}$ & $\begin{array}{c}0.644 \\
(0.859)\end{array}$ & $\begin{array}{c}0.0002 \\
(0.0004)\end{array}$ \\
\hline $\begin{array}{l}\delta_{5} \text { Industry Perf. * } \\
\text { Industry Beta }\end{array}$ & $\begin{array}{l}3.188 \\
(1.478)\end{array}$ & $\begin{array}{l}1.678 \\
(1.901)\end{array}$ & $\begin{array}{c}0.0003 \\
(0.0004)\end{array}$ & $\begin{array}{c}0.688 \\
(0.425)\end{array}$ & $\begin{array}{c}0.629 \\
(0.673)\end{array}$ & $\begin{array}{c}0.0001 \\
(0.0003)\end{array}$ \\
\hline $\begin{array}{c}\delta_{6} \text { Industry Perf. * } \\
\text { CDF * Beta }\end{array}$ & $\begin{array}{l}-3.427 \\
(1.606)\end{array}$ & $\begin{array}{l}-1.999 \\
(2.072)\end{array}$ & $\begin{array}{l}-0.0003 \\
(0.0004)\end{array}$ & $\begin{array}{l}-0.756 \\
(0.474)\end{array}$ & $\begin{array}{l}-0.725 \\
(0.732)\end{array}$ & $\begin{array}{l}-0.0002 \\
(0.0004)\end{array}$ \\
\hline$\delta_{7} \mathrm{CDF}$ of Variance & $\begin{array}{l}3205 \\
(2507)\end{array}$ & $\begin{array}{l}3099 \\
(2471)\end{array}$ & $\begin{array}{l}-0.1290 \\
(0.4258)\end{array}$ & $\begin{array}{l}1661 \\
(730)\end{array}$ & $\begin{array}{l}1941 \\
(924)\end{array}$ & $\begin{array}{c}0.2807 \\
(0.3239)\end{array}$ \\
\hline$\delta_{8}$ Industry Beta & $\begin{array}{l}-375 \\
(391)\end{array}$ & $\begin{array}{c}176 \\
(535)\end{array}$ & $\begin{array}{l}-0.0656 \\
(0.1397)\end{array}$ & $\begin{array}{c}81 \\
(141)\end{array}$ & $\begin{array}{l}207 \\
(206)\end{array}$ & $\begin{array}{c}0.0629 \\
(0.1024)\end{array}$ \\
\hline$\delta_{9} \mathrm{CDF} *$ Beta & $\begin{array}{c}369 \\
(1351)\end{array}$ & $\begin{array}{l}-1205 \\
(1701)\end{array}$ & $\begin{array}{l}-0.1454 \\
(0.2947)\end{array}$ & $\begin{array}{l}-755 \\
(557)\end{array}$ & $\begin{array}{l}-1388 \\
(754)\end{array}$ & $\begin{array}{l}-0.2985 \\
(0.2134)\end{array}$ \\
\hline $\begin{array}{l}\alpha_{1} \text { Own Firm } \\
\text { Sensitivity }\end{array}$ & $\begin{array}{c}0.537 \\
{[0.198]}\end{array}$ & $\begin{array}{c}\mathrm{Co} \\
0.885 \\
{[0.129]}\end{array}$ & $\begin{array}{l}\text { tive Statics } \\
0.0003 \\
{[0.000]}\end{array}$ & $\begin{array}{c}\text { P-values } \\
0.130 \\
{[0.081]}\end{array}$ & $\begin{array}{c}\text { ckets] } \\
0.287 \\
{[0.018]}\end{array}$ & $\begin{array}{l}0.0002 \\
{[0.000]}\end{array}$ \\
\hline $\begin{array}{ll}\alpha_{2} & \text { Industry } \\
& \text { Sensitivity }\end{array}$ & $\begin{array}{c}-0.180 \\
{[0.774]}\end{array}$ & $\begin{array}{c}0.102 \\
{[0.890]}\end{array}$ & $\begin{array}{l}-0.0001 \\
{[0.093]}\end{array}$ & $\begin{array}{c}-0.057 \\
{[0.481]}\end{array}$ & $\begin{array}{c}0.030 \\
{[0.823]}\end{array}$ & $\begin{array}{c}-0.00004 \\
{[0.522]}\end{array}$ \\
\hline $\begin{array}{l}\text { Derivative of }\left(\alpha_{2} / \alpha_{1}\right) \\
\text { H1: Zero } \\
\text { H2: Negative one }\end{array}$ & $\begin{array}{l}2.746 \\
{[0.311]} \\
{[0.167]}\end{array}$ & $\begin{array}{c}0.767 \\
{[0.532]} \\
{[0.150]}\end{array}$ & $\begin{array}{c}0.490 \\
{[0.444]} \\
{[0.020]}\end{array}$ & $\begin{array}{c}2.385 \\
{[0.271]} \\
{[0.119]}\end{array}$ & $\begin{array}{c}0.930 \\
{[0.435]} \\
{[0.105]}\end{array}$ & $\begin{array}{c}0.222 \\
{[0.755]} \\
{[0.086]}\end{array}$ \\
\hline Observations & 4620 & 4172 & 4166 & 19868 & 15291 & 15286 \\
\hline
\end{tabular}

Notes:

1) Each regression includes year effects and executive fixed effects.

2) Heteroskedasticity robust standard errors are in parentheses below coefficients. For regressions on the sample of other executives, the standard errors are robust to correlation among executives at the same firm in each year.

3) Compensation is measured in thousands and dollar returns are measured in millions of 1995 dollars.

4) The pay-performance sensitivities are $\alpha_{1}=\delta_{1}+0.5 * \delta_{2}$ and $\alpha_{2}=\delta_{3}+0.5 * \delta_{4}+1 * \delta_{5}+0.5 * 1 * \delta_{6}$. 
Table 9

Tests of Relative Performance Evaluation at the 2-digit SIC Level, Percent Returns, OLS Regressions, 1993 - 1996

\begin{tabular}{|c|c|c|c|c|c|c|}
\hline & \multicolumn{3}{|c|}{ Chief Executive Officers } & \multicolumn{3}{|c|}{ Other Executives } \\
\hline & $\begin{array}{l}\text { Flow } \\
\text { Comp. }\end{array}$ & $\begin{array}{l}\text { Change } \\
\text { in Flow }\end{array}$ & $\begin{array}{l}\text { \% Change } \\
\text { in Flow }\end{array}$ & $\begin{array}{l}\text { Flow } \\
\text { Comp. }\end{array}$ & $\begin{array}{l}\text { Change } \\
\text { in Flow }\end{array}$ & $\begin{array}{l}\% \text { Change } \\
\text { in Flow }\end{array}$ \\
\hline Percent Returns & \multicolumn{6}{|c|}{ Coefficients from OLS Regressions } \\
\hline$\delta_{1}$ Performance & $\begin{array}{l}14.675 \\
(9.033)\end{array}$ & $\begin{array}{c}17.168 \\
(11.489)\end{array}$ & $\begin{array}{c}0.0060 \\
(0.0012)\end{array}$ & $\begin{array}{c}4.592 \\
(1.620)\end{array}$ & $\begin{array}{c}8.452 \\
(3.033)\end{array}$ & $\begin{array}{c}0.0052 \\
(0.0008)\end{array}$ \\
\hline $\begin{array}{l}\delta_{2} \text { Performance } * \\
\text { CDF of Variance }\end{array}$ & $\begin{array}{l}-15.428 \\
(11.102)\end{array}$ & $\begin{array}{l}-12.476 \\
(14.513)\end{array}$ & $\begin{array}{l}-0.0045 \\
(0.0016)\end{array}$ & $\begin{array}{l}-5.355 \\
(1.960)\end{array}$ & $\begin{array}{l}-8.997 \\
(3.718)\end{array}$ & $\begin{array}{l}-0.0046 \\
(0.0011)\end{array}$ \\
\hline $\begin{array}{l}\delta_{3} \text { Industry } \\
\text { Performance }\end{array}$ & $\begin{array}{l}-11.710 \\
(15.183)\end{array}$ & $\begin{array}{c}-3.660 \\
(20.839)\end{array}$ & $\begin{array}{c}-0.000005 \\
(0.0041)\end{array}$ & $\begin{array}{l}-3.907 \\
(4.138)\end{array}$ & $\begin{array}{l}-0.337 \\
(7.151)\end{array}$ & $\begin{array}{l}-0.0007 \\
(0.0033)\end{array}$ \\
\hline $\begin{array}{l}\delta_{4} \text { Industry Perf. } * \\
\text { CDF of Variance }\end{array}$ & $\begin{array}{c}-5.313 \\
(23.401)\end{array}$ & $\begin{array}{c}1.536 \\
(32.880)\end{array}$ & $\begin{array}{l}-0.0036 \\
(0.0072)\end{array}$ & $\begin{array}{c}0.635 \\
(6.014)\end{array}$ & $\begin{array}{c}-1.443 \\
(10.603)\end{array}$ & $\begin{array}{c}0.0008 \\
(0.0057)\end{array}$ \\
\hline $\begin{array}{l}\delta_{5} \text { Industry Perf. * } \\
\text { Industry Beta }\end{array}$ & $\begin{array}{c}-4.722 \\
(14.908)\end{array}$ & $\begin{array}{c}-3.052 \\
(19.787)\end{array}$ & $\begin{array}{l}-0.0023 \\
(0.0039)\end{array}$ & $\begin{array}{c}1.995 \\
(3.946)\end{array}$ & $\begin{array}{l}-0.802 \\
(6.588)\end{array}$ & $\begin{array}{l}-0.0003 \\
(0.0032)\end{array}$ \\
\hline $\begin{array}{c}\delta_{6} \text { Industry Perf. * } \\
\text { CDF * Beta }\end{array}$ & $\begin{array}{c}19.086 \\
(23.785)\end{array}$ & $\begin{array}{c}-1.101 \\
(32.506)\end{array}$ & $\begin{array}{c}0.0050 \\
(0.0068)\end{array}$ & $\begin{array}{c}0.613 \\
(5.896)\end{array}$ & $\begin{array}{c}3.644 \\
(10.130)\end{array}$ & $\begin{array}{c}0.0001 \\
(0.0054)\end{array}$ \\
\hline$\delta_{7} \mathrm{CDF}$ of Variance & $\begin{array}{l}1196 \\
(1357)\end{array}$ & $\begin{array}{l}1155 \\
(1706)\end{array}$ & $\begin{array}{c}0.2055 \\
(0.3592)\end{array}$ & $\begin{array}{c}399 \\
(325)\end{array}$ & $\begin{array}{c}443 \\
(532)\end{array}$ & $\begin{array}{c}0.0076 \\
(0.2797)\end{array}$ \\
\hline$\delta_{8}$ Industry Beta & $\begin{array}{l}1473 \\
(876)\end{array}$ & $\begin{array}{c}393 \\
(840)\end{array}$ & $\begin{array}{l}-0.2211 \\
(0.1725)\end{array}$ & $\begin{array}{c}-22 \\
(200)\end{array}$ & $\begin{array}{l}-272 \\
(324)\end{array}$ & $\begin{array}{l}-0.1142 \\
(0.1410)\end{array}$ \\
\hline$\delta_{9} \mathrm{CDF} *$ Beta & $\begin{array}{l}-2211 \\
(1156)\end{array}$ & $\begin{array}{l}-778 \\
(1220)\end{array}$ & $\begin{array}{c}0.1289 \\
(0.2621)\end{array}$ & $\begin{array}{l}-297 \\
(331)\end{array}$ & $\begin{array}{l}-187 \\
(497)\end{array}$ & $\begin{array}{c}0.0914 \\
(0.2060)\end{array}$ \\
\hline $\begin{array}{c}\alpha_{1} \text { Own Firm } \\
\text { Sensitivity }\end{array}$ & $\begin{array}{c}6.961 \\
{[0.057]}\end{array}$ & $\begin{array}{r}\text { Co } \\
10.930 \\
{[0.017]}\end{array}$ & $\begin{array}{l}\text { ative Statics } \\
0.0038 \\
{[0.000]}\end{array}$ & $\begin{array}{c}\text { P-values } \\
1.914 \\
{[0.005]}\end{array}$ & $\begin{array}{l}\text { ckets] } \\
3.953 \\
{[0.001]}\end{array}$ & $\begin{array}{l}0.0030 \\
{[0.000]}\end{array}$ \\
\hline $\begin{array}{ll}\alpha_{2} & \text { Industry } \\
\text { Sensitivity }\end{array}$ & $\begin{array}{l}-9.545 \\
{[0.207]}\end{array}$ & $\begin{array}{l}-6.494 \\
{[0.391]}\end{array}$ & $\begin{array}{l}-0.0016 \\
{[0.104]}\end{array}$ & $\begin{array}{l}-1.289 \\
{[0.252]}\end{array}$ & $\begin{array}{l}-0.038 \\
{[0.984]}\end{array}$ & $\begin{array}{l}-0.0005 \\
{[0.592]}\end{array}$ \\
\hline $\begin{array}{l}\text { Derivative of }\left(\alpha_{2} / \alpha_{1}\right) \\
\text { H1: Zero } \\
\text { H2: Negative one }\end{array}$ & $\begin{array}{c}0.693 \\
{[0.518]} \\
{[0.114]}\end{array}$ & $\begin{array}{l}-0.330 \\
{[0.645]} \\
{[0.349]}\end{array}$ & $\begin{array}{c}0.037 \\
{[0.930]} \\
{[0.015]}\end{array}$ & $\begin{array}{c}1.202 \\
{[0.232]} \\
{[0.029]}\end{array}$ & $\begin{array}{c}0.258 \\
{[0.717]} \\
{[0.077]}\end{array}$ & $\begin{array}{l}-0.066 \\
{[0.891]} \\
{[0.051]}\end{array}$ \\
\hline Observations & 4620 & 4172 & 4166 & 19868 & 15291 & 15286 \\
\hline
\end{tabular}

Notes:

1) Each regression includes year effects and executive fixed effects.

2) Heteroskedasticity robust standard errors are in parentheses below each estimate. For regressions on the sample of other executives, the standard errors are robust to correlation among executives at the same firm in each year.

3) Compensation is measured in thousands of 1995 dollars. Percent returns are measured in percentage points.

4) The pay-performance sensitivities are $\alpha_{1}=\delta_{1}+0.5 * \delta_{2}$ and $\alpha_{2}=\delta_{3}+0.5 * \delta_{4}+1 * \delta_{5}+0.5 * 1 * \delta_{6}$. 